LABAuGst, J.W, G.E. Groschen, \& T.C. Winter 1981

LIMNOLOGICAL AND GEOCHEMICAL SURVEY OF WILLIAMS LAKE, HUBBARD COUNTY, MINNESOTA
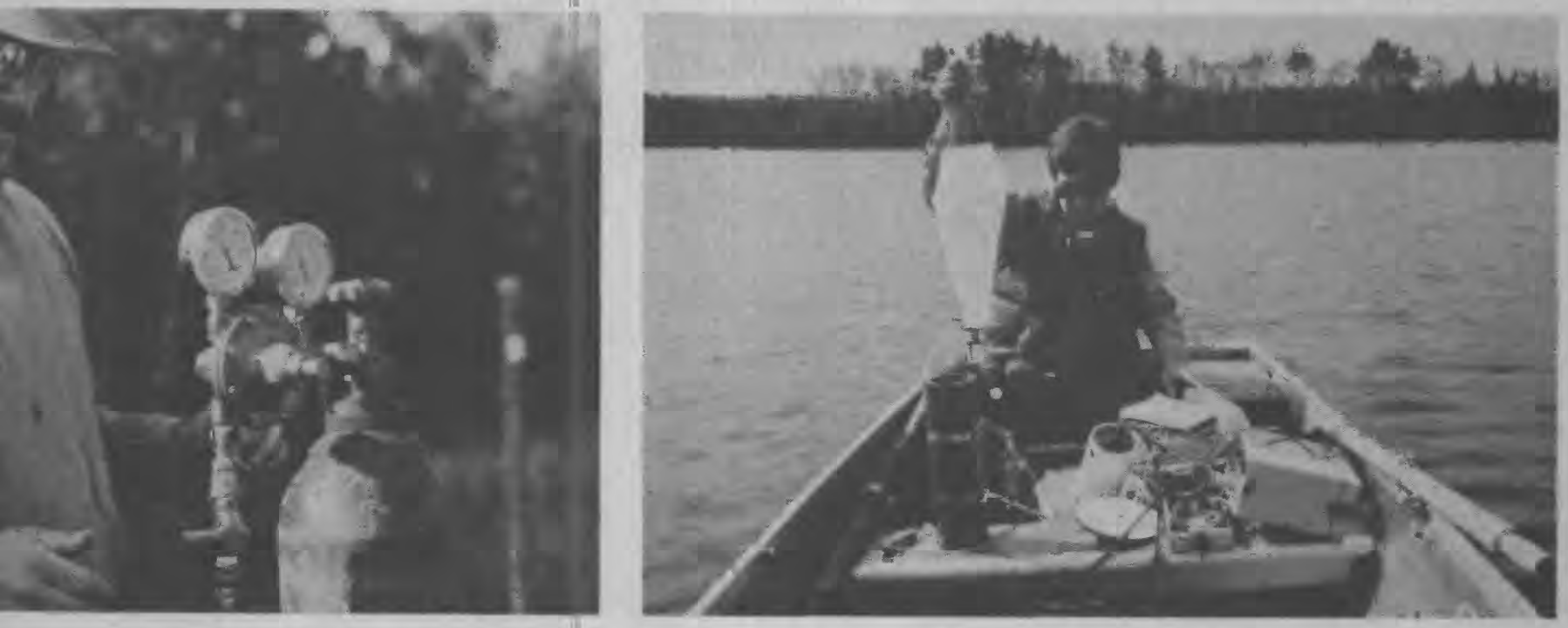

U.S. GEOLOGICAL SURVEY WATER-RESOURCES INVESTIGATIONS 81-41

Prepared in cooperation with tho Minnesota Department of Natural Resources

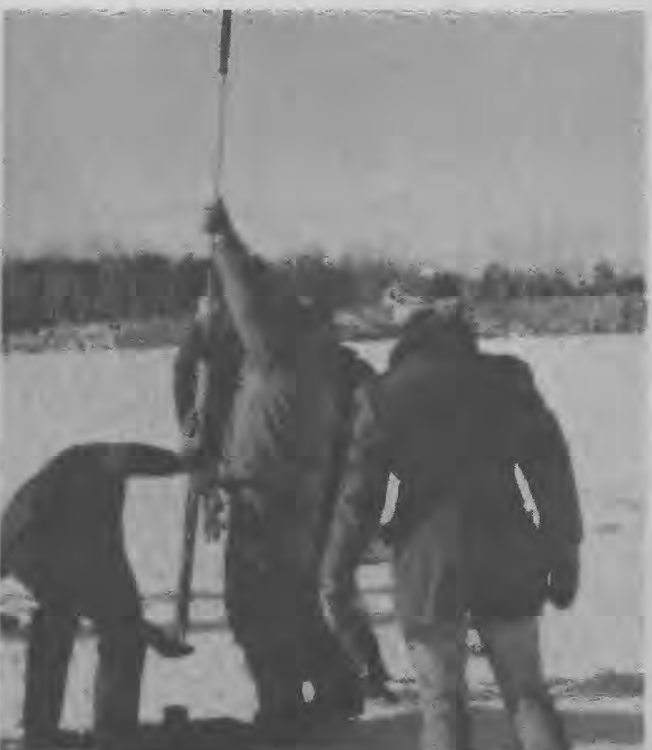




\section{$50272-101$ \\ REPORT 'DOCUMENTATION \\ PAGE \\ 4. Titte and Subtitle}

LIMNOLOGICAL AND GEOCHEMICAL SURVEY OF WILLIAMS LAKE

HUBBARD COUNTY, MINNESOTA

\section{Author(s)}

J. W. LaBaugh, G. E. Groschen and T. C. Winter 9. Performing Organization Name and Address

U.S. Geological Survey, Water Resources Division Box 25046, Mail Stop 406, Denver Federal Center Lakewood, CO 80225
3. Recipient's Accession No.

\section{Report Date}

September 1981

6.

8. Porforming Organization Rept. N USGS/WRI $81-41$

10. Project/Task/Work Unit No.

11. Contract(C) or Grant(G) No.

(C)

(G)

13. Type of Report \& Period Covere

Progress

\section{U.S. Geological Survey, Water Resources Division}

Box 25046, Mail Stop 406, Denver Federal Center

Lakewood, CO 80225

14.

\section{Supplementary Notes}

16. Abstract (Limit: 200 words) A limnological and geochemical survey of Williams Lake, Minnesota wa made in 1979 to provide an initial interpretative description of the lake and the conti uous ground-water system. This survey was made as part of a continuing research prograt related to the investigation of the interaction of lakes and their contiguous ground-wa systems at Williams Lake, Minnesota, as well as other sites within the continental Unit States. During 1979, Williams Lake was dimictic, and the lake had high optical transpa ancy; light penetrated to the lakebed throughout most of the lake. Aquatic macrophytes were present along the western shore and in the southern bay of the lake. Although the lake had clinograde-oxygen distributions during part of this survey, anaerobic conditio were not observed. The lake is moderately fertile with respect to its total phosphorus tent. Nutrient data indicate phosphorus limits phytoplankton biomass levels in William Lake. Blue-green algae were the dominant group of the phytoplankton community and cope were the dominant group of the zooplankton community when the lake was thermally strati during the open-water season. Diatoms and rotifers were dominant when the lake was iso thermal in the autumn. Calcium and bicarbonate represent more than 90 percent of the dissolved constituents in Williams Lake and the contiguous ground-water system. Major m eralogical constituents of the lake sediments are quartz, dolomite, and calcite. Mar1 present only in the littoral zone of the lake. Organic sediments in the lake consist o loose organic floc and gyttja.

17. Document Analysis a. Descriptors Limnology, Geochemistry, Mineralogy, Lakes, Ground water, Sed imen Phytoplankton, Zooplankton, Aquatic plants

b. Identifiers/Open-Ended Torms Minnesota, Hubbard County

c. COSATI Field/Group 
LIMNOLOGICAL AND GEOCHEMICAL SURVEY OF WILLIAMS LAKE, HUBBARD COUNTY, MINNESOTA

By J. W. LaBaugh, G. E. Groschen, and T. C. Winter

U. S. GEOLOGICAL SURVEY

WATER-RESOURCES INVESTIGATIONS 81-41

Prepared in cooperation with the

Minnesota Department of Natural Resources

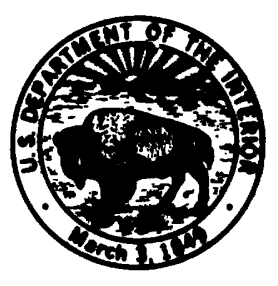

Denver, Colorado

1981 
UNITED STATES DEPARTMENT OF THE INTERIOR

JAMES G. WATT, Secretary

GEOLOGICAL SURVEY

Doyle G. Frederick, Acting Director

For additional information write to:

Regional Hydrologist

Water Resources Division, Central Region

U.S. Geological Survey

Box 25046, Mail Stop 406

Denver Federal Center

Denver, Colorado 80225 


\section{CONTENTS}

Abstract-_-_-_-_-_-_-_- 1

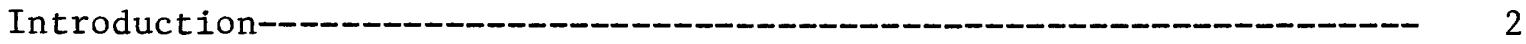

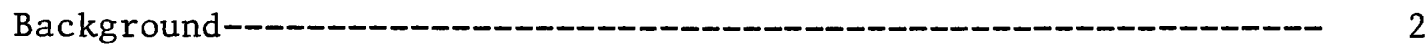

Purpose and scope-_-_-_-_-_-_-_-_-_-_-_-_-_-_-_-_-_-_-_ 5

Acknowledgments--_-_-_- 5

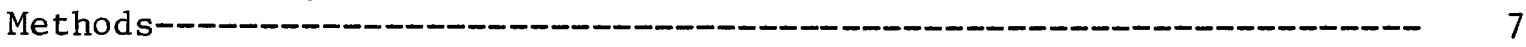

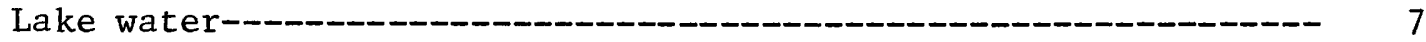

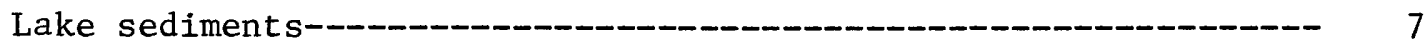

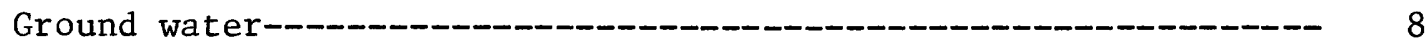

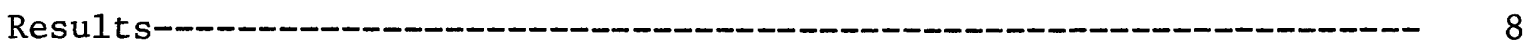

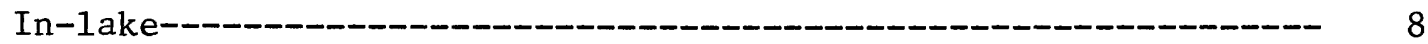

Lake-sediment mineralogy-_-_-_-_-_-_-_-_-_-_-_-_-_-_-_-_ 18

Ground water-_-_-_-_- 22

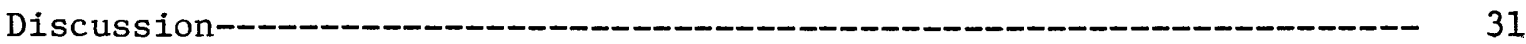

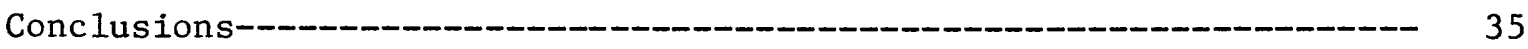

References-_-_-_-__-__-_-_-_ 36

\section{ILLUSTRATIONS}

Figure 1. Map showing location of Williams Lake, Minnesota-_-_-_-- 3

2. Soil types and geomorphic features near Williams Lake

(modified from Siegel and Winter, 1980)-...-..- 4

3. Map and geologic section, Williams Lake, (modified from

Siegel and Winter, 1980)-_-_-_-_-_-_-_-_-_ 6

A. Map showing bathymetry and location of sediment

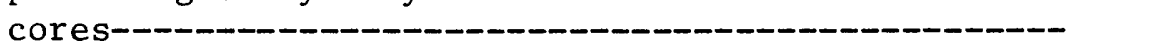

B. Section showing stratigraphy of lake sediments and location of subsamples for mineralogical analysis

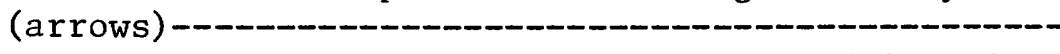

4. Hydrologic instrumentation at Williams Lake and locations of wells used for sampling ground-water quality--------

5. Vertical distribution of temperature (A), dissolved oxygen (B), and $\mathrm{pH}$ and specific conductance (C) in Williams Lake on 6 days in 1979-_-_-_-

6. Major ion concentrations for near-surface and near-bottom samples of Williams Lake on 6 days in 1979

7. Iron and manganese concentrations for near-surface and near-bottom samples of Williams Lake on 6 days in $1979-190$ -

8. Near-surface and near-bottom concentrations of silica in Williams Lake on 6 days in 1979-_- 
Figure 9. Near-surface and, near-bottom concentrations for phosphorus and nitrogen in Williams Lake on 6 days in 1979. Analyses for total phosphorus and Kjeldahl nitrogen were not made for the October and December sampling

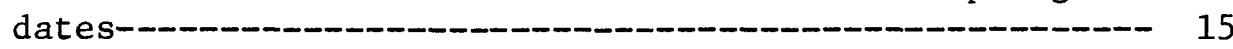

10. Percent composition of the phytoplankton community of Williams Lake on 6 days in 1979, based on cell counts-_-_-_-_-- 16

11. Percent composition of the zooplankton community of Williams Lake on 6 days in 1979, based on counts from two replicate vertical hauls-_-_-_-_--- 19

12. Phytoplankton numbers, chlorophyll concentrations, and zooplankton numbers for Williams Lake on 6 days in 1979

13. Chemical characteristics of ground-water for selected piezometers of nest $\mathrm{W}$ and for lake-water at 1 meter depth, October 19, 1979: Major ion concentrations (A) - 29 dissolved iron and manganese concentrations (B)--.-.-- 30

14. Chemical characteristics of ground water from watertable wells near Williams Lake, showing changes in water chemistry related to distance of movement of lake water that seeped to ground water-_-_-_-_-_--

\section{TABLES}

Table 1. Morphometric characteristics of Williams Lake--_-_-_-_ 5

2. Phytoplankton genera found in Williams Lake, Minnesota, on

3. Zooplankton genera found in Williams Lake, Minnesota, on

6 days in 1979-_. 20

4. Lithologic description of lake-sediment cores---_-_--- 23

5. Bulk-mineral composition of selected sections of Williams

Lake sediment cores-_- 24

6. Physical properties and mean concentrations of dissolved chemical constituents for wells sampled periodically----- 25

7. Physical properties and concentrations of dissolved constituents for wells sampled once-_-_-_-_-_-_-_ 26

8. Physical properties and concentrations of chemical constituents in water from piezometer nest $\mathrm{W}$; all wells were sampled October 19, 1979-_._-_._- 


\section{CONVERSION FACTORS}

For the convenience of those readers who prefer to use U.S. customary units rather than the international system of units (SI), the conversion factors for terms used in this report are listed below:

Mu1tiply SI unit

micrometer $(\mu \mathrm{m})$

millimeter $(\mathrm{mm})$

centimeter $(\mathrm{cm})$

meter (m)

square meter $\left(\mathrm{m}^{2}\right)$

cubic meter $\left(\mathrm{m}^{3}\right)$

1iter (L)

milligram per liter (mg/L)

milligram per cubic meter $\left(\mathrm{mg} / \mathrm{m}^{3}\right)$

microgram per liter ( $\mu \mathrm{g} / \mathrm{L}) \quad 6.242 \times 10^{-8}$ siemens (S)
By

0.039

0.393

3.281

$2.471 \times 10^{-4}$

35.31

$3.531 \times 10^{-2}$

$6.242 \times 10^{-5}$

$6.242 \times 10^{-8}$

1
To obtain U.S. customary unit

inch (in)

inch (in)

inch (in)

feet $(f t)$

acre

cubic foot $\left(\mathrm{ft}^{3}\right)$

cubic foot $\left(\mathrm{ft}^{3}\right)$

pound per cubic foot $\left(1 \mathrm{~b} / \mathrm{ft}^{3}\right)$

pound per cubic foot $\left(1 \mathrm{~b} / \mathrm{ft}^{3}\right)$

pound per cubic foot $\left(1 b / f t^{3}\right)$

mhos

National Geodetic Vertical Datum of 1929 (NGVD of 1929).--A geodetic datum derived from a general adjustment of the first-order level nets of both the United States and Canada, formerly called "mean sea level." The datum was derived from the average sea level over a period of many years at 26 tide stations along the Atlantic, Gulf of Mexico, and Pacific coasts.

Brand names used in this report are for identification only and do not imply endorsement by the U.S. Geological Survey. 



\title{
LIMNOLOGICAL AND GEOCHEMICAL SURVEY OF WILLIAMS LAKE, HUBBARD COUNTY, MINNESOTA
}

\author{
By J. W. LaBaugh, G. E. Groschen, and T. C. Winter
}

\begin{abstract}
A limnological and geochemical survey of Williams Lake, Minnesota, was made in 1979 to provide an initial interpretive description of the lake and the contiguous ground-water system. This survey was made as part of a continuing research program related to the investigation of the interaction of lakes and their contiguous ground-water systems at Williams Lake, Minnesota, as well as other sites within the continental United States.

During 1979, Williams Lake was dimictic, and the lake had high optical transparency; light penetrated to the lakebed throughout most of the lake. Aquatic macrophytes were present along the western shore and in the southern bay of the lake. Although the lake had clinograde-oxygen distributions during part of this survey, anaerobic conditions were not observed. The lake is moderately fertile with respect to its total phosphorus content. Nutrient data indicate phosphorus limits phytoplankton biomass levels in Williams Lake. Blue-green algae were the dominant group of the phytoplankton community and copepods were the dominant group of the zooplankton community when the lake was thermally stratified during the open-water season. Diatoms and rotifers were dominant when the lake was isothermal in the autumn.

Calcium and bicarbonate represent more than 90 percent of the dissolved constituents in Williams Lake and the contiguous ground-water system. Major mineralogical constituents of the lake sediments are quartz, dolomite, and calcite. Marl is present only in the littoral zone of the lake. Organic sediments in the lake consist of loose organic floc and gyttja.
\end{abstract}




\section{INTRODUCTION}

\section{Background}

The need for research on nutrient balances of lakes has been amply demonstrated in recent years by increased activity in the field of lake management and restoration (Seyb and Randolph, 1977; U.S. Environmental Protection Agency, 1979). Although water and nutrient balances are required for assessment of lake management and restoration projects, many field and analytical methods are subject to various amounts of error (Winter, 1980). Because of uncertainties in hydrologic methods related to lakes (Winter, 1981), the U.S. Geological Survey recent1y initiated research studies on the physical, chemical, and biological aspects of lake hydrology.

Williams Lake, a smal1 natural lake in north-central Minnesota (fig. 1), is one of several natural lakes selected by the U.S. Geological Survey and its cooperators for intensive field research. The lake was selected partly because it has no surface-water inlets or outlets; it was perceived to be a relatively simple hydrologic system, interacting only with the atmosphere and with ground water. Based on National Weather Service data obtained at stations tens of miles from Williams Lake, the lake is in an area where precipitation is approximately equal to evaporation. As part of the U.S. Geological Survey's lake hydrology program, Williams Lake has been instrumented for evaluation of several methods of measuring and estimating precipitation, evaporation, and ground-water interchange.

Williams Lake lies immediately south of the Itasca moraine at an altitude of about 420 meters above the National Geodetic Vertical Datum of 1929. The lake is immediately underlain by sand and gravel, but deep test drilling indicates that this surficial unit is underlain by a complex series of alternating till and sand and gravel units. Although the geomorphic setting of the lake is characteristic of ice-contact drift, the lake is shown by Arneman and others (1969) to be near the northern boundary of the Park Rapids-Staples Outwash Plain (fig. 2). The physical setting of Williams Lake, as well as hydrologic instrumentation and preliminary evaluation of its hydrologic setting, is described by Siegel and Winter (1980). The morphometric characteristics of the lake are shown in table 1 and figure 3 .

Because Williams Lake is instrumented for extensive hydrologic studies, it is an ideal site for limnological research that is dependent on knowledge of hydrologic fluxes to and from the lake. The limnological characteristics of Williams Lake have never been studied. Therefore, a 1 -year survey was made in 1979 so a basic description of the 1imnological characteristics of the lake would be available. 


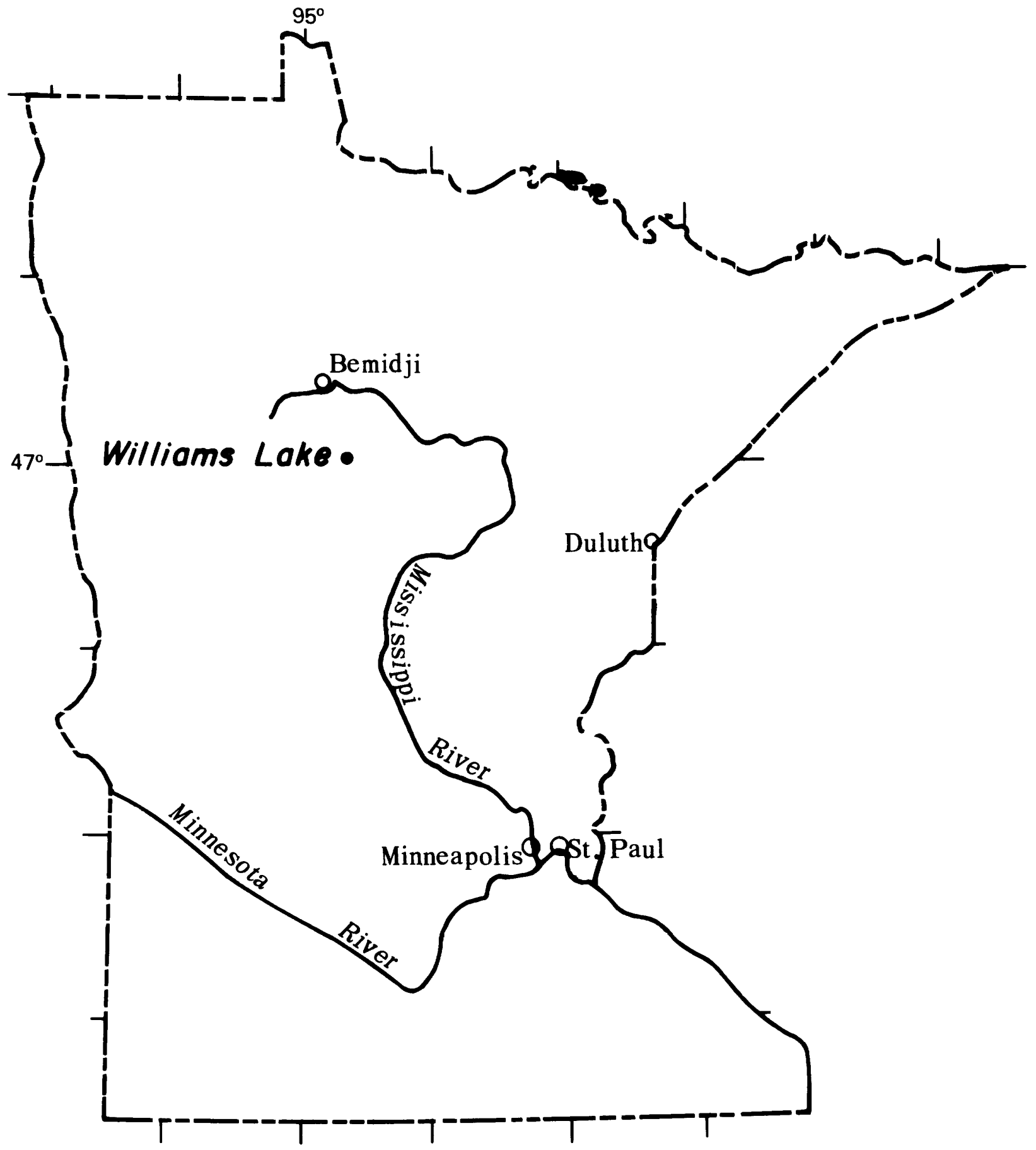

Figure 1. - - Location of Williams Lake, Minnesota 


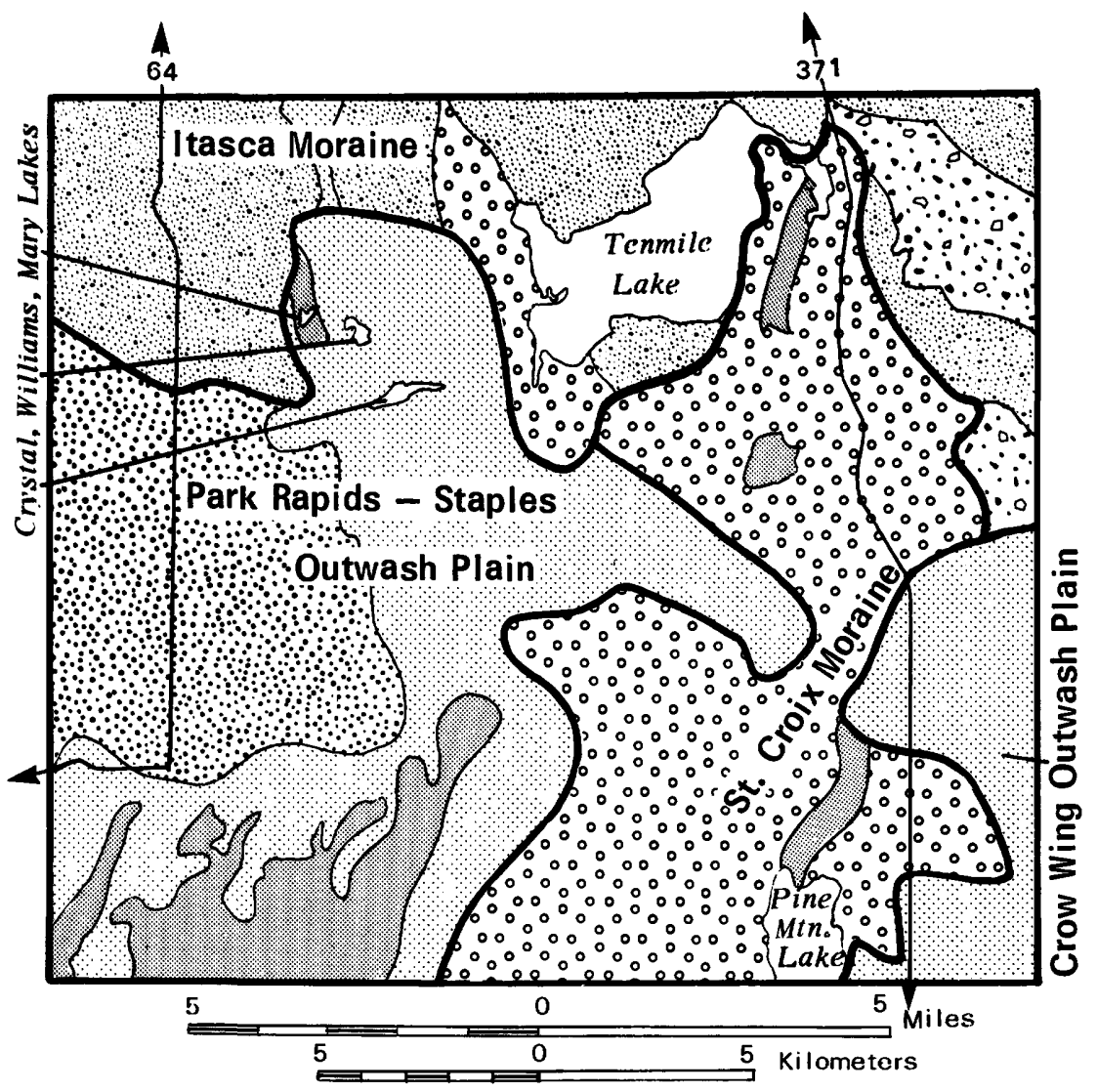

EXPLANATION

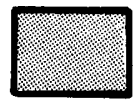

Peat

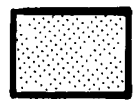

Sandy over sandy

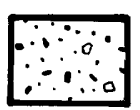

Silty or loamy over clayey

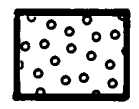

Loamy over mixed sandy and loamy

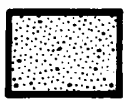

Deep silty over loamy

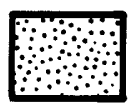

Loamy over sandy

Geomorphic contact

Soil - type contact

Figure 2. --Soil types and geomorphic features near Williams Lake (modified from Siegel and Winter, 1980) 
Table 1. - - Morphometric characteristics of Williams Lake

Characteristics

Size, in meters, (m)

Surface area

Drainage basin area

$3.64 \times 10^{5} \mathrm{~m}^{2}$

Maximum depth

Mean depth $\left(\frac{\text { lake volume }}{\text { lake area }}\right)$

$2.26 \times 10^{6} \mathrm{~m}^{2}$

Maximum length

$10.6 \pm 0.9 \mathrm{~m}$

Orientation

$5.18 \mathrm{~m}$

Maximum width

$981.4 \mathrm{~m}$

Mean width

NW - SE

Volume

Development of volume $\left(\frac{3 \text { (mean depth) }}{\text { maximum depth }}\right)$

$530.3 \mathrm{~m}$

$377.9 \mathrm{~m}$

$1.89 \times 10^{6} \mathrm{~m}^{3}$

Length of shoreline

Development of shoreline $\frac{\text { length of shoreline }}{2 \sqrt{\pi(\text { area of lake })}}$

1.5 (dimensionless)

$2874.2 \mathrm{~m}$

1.3 (dimension1ess)

\section{Purpose and scope}

The purpose of this report is to describe and make preliminary interpretations of: (1) Limnological characteristics of Williams Lake, based on physical, chemical, and biological data collected in 6 days in 6 different months in 1979; (2) chemical quality of ground water near the lake, based on samples collected during the summer of 1979; and (3) mineralogy of the lake sediment cores obtained in February 1978. The period of study extended from March, when the lake was covered by ice, through the period of open water, to December, when it was again covered by ice.

\section{Acknowledgements}

We wish to thank Dr. William Taylor, Department of Fisheries and Wildlife, Michigan State University for the zooplankton analyses; and Dr. Blair F. Jones, U.S. Geological Survey, for mineralogical analyses of the lake sediments. 

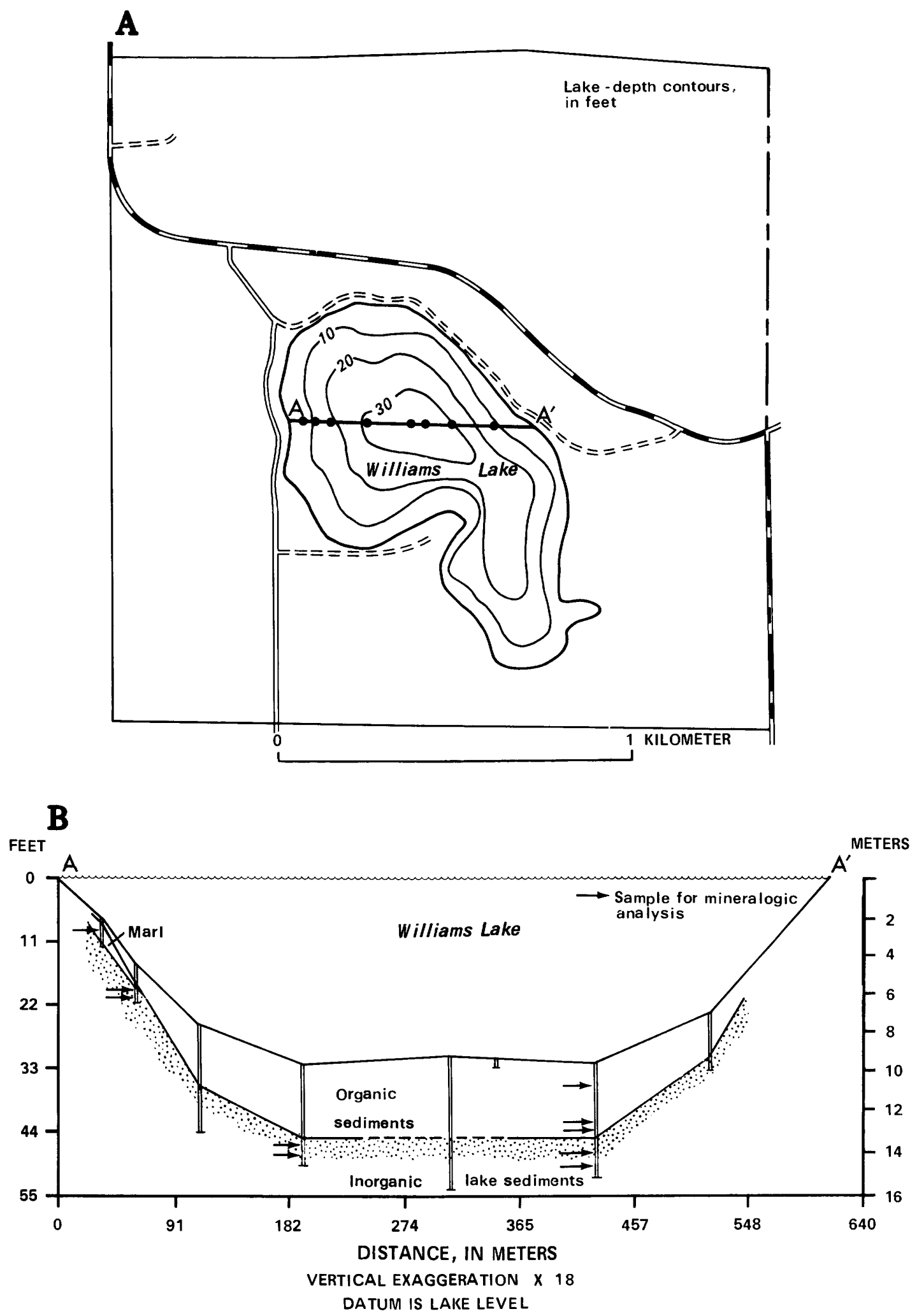

Figure 3. - - Map and geologic section, Williams Lake, (modified from Siegel and Winter, 1980) A. Bathymetry and location of sediment cores B. Stratigraphy of lake sediments and location of subsamples for mineralogical analysis (arrows) 


\section{METHODS}

\section{Lake water}

Williams Lake was sampled in March, May, July, August, October, and December of 1979 for physical, chemical, and biological characteristics. The sampling location was over the deepest part of the lake (fig. 3). Optical transparency was measured with a $20-\mathrm{cm}$ (centimeter) diameter white Secchi disk. A multiparameter probe was used to measure temperature, specific conductance, dissolved oxygen, and $\mathrm{pH}$ at $1-\mathrm{m}$ (meter) intervals along a vertical profile through the water column.

Samples for major ion, iron, manganese, total phosphorus, total nitrogen, and silica concentrations were collected with a 2-L (1iter) PVC horizontal Alpha bottle at $1 \mathrm{~m}$ below the lake surface (hereafter referred to as nearsurface samples) and at $1 \mathrm{~m}$ above the lake bottom (hereafter referred to as near-bottom samples). The Alpha bottle also was used to obtain discretedepth samples from the euphotic zone, that was determined by doubling the Secchi disk transparency value (Dillon and Rigler, 1974). These discretedepth samples were combined into one 2-L sample, which was then split into two 1-L subsamples: One for phytoplankton analysis, and the other for chlorophyl1 a analysis. The subsample for phytoplankton analysis was preserved with a formalin-copper sulfate solution. The subsample for chlorophy11 a analysis was filtered through a glass-fiber filter, then analyzed by chromatography and fluorometry (Shoaf and Lium, 1977).

Zooplankton were collected in replicate vertical hauls from 1-meter above lake bottom to the surface, using an 80- $\mu \mathrm{m}$ (micrometer) mesh Wisconsin plankton net. Zooplankton samples were narcotized with soda water and then fixed with formalin.

A11 samples except zooplankton were analyzed by the U.S. Geological Survey national water quality laboratory in Doraville, Georgia, according to methods described in Skougstad and others (1979) for water chemistry and Greeson and others (1977) for biological determinations. Zooplankton were identified and enumerated by Dr. William Taylor, Department of Fisheries and Wildlife, Michigan State University.

\section{Lake sediments}

Cores of lake sediment were taken at seven locations in Williams Lake February 19-20, 1978 ( $\mathrm{fig}$. 3). The cores were taken with a 50-cm diameter piston corer, using core barrels of 1, 2, and (or) 3.5-m lengths. The sediment was extruded onsite and wrapped in plastic-film wrap and aluminum foil. The cores were later split in half, cut into 5-cm segments, 
and stored. Ten samples of lake sediment (fig. 3) were analyzed by Dr. Blair F. Jones, U.S. Geological Survey, for their mineralogical composition using $\mathrm{X}$-ray diffraction (Jones and Bowser, 1979).

\section{Ground water}

Samples of ground water for chemical analysis were collected with a bailer, modified from the design of Wood (1976), because the wells have small diameters ( $5 \mathrm{~cm}$ or less) and most are water-table wells containing less than $2 \mathrm{~m}$ of water. Each well sampled (see fig. 4 for locations) was bailed until approximately four casing volumes had moved through the screen, or until constant temperature, $\mathrm{pH}$, and specific conductance were obtained. Temperature was measured either by a thermister or a calibrated mercury thermometer. Specific conductance was measured with a specific conductance bridge adjusted to the water temperature and a plastic-graphite dip cell. In the range of specific conductance encountered, 100 to $500 \mu \mathrm{S} / \mathrm{cm}$ (microsiemens per centimeter) the indicated values were all within 5 percent error. A $\mathrm{pH}$ meter and combinatio glass electrode were used to measure $\mathrm{pH}$. All pH measurements were preceded by double buffer checks with 7.00 and 4.00 or 10.00 ( \pm 0.02 units) buffers cooled to ground-water temperature.

Alkalinity was determined in the field by titration with standardized sulfuric acid. Calcium and magnesium were determined by EDTA compleximetric titrations using Eriochrome Black T indicator (Brown and others, 1970). Calcium was determined by a similar titration at a higher $\mathrm{pH}$ using hydroxynapthol blue indicator. Other constituents were determined by the U.S. Geological Survey national water quality laboratory in Doraville, Georgia, according to standard techniques (Skougstad and others, 1979).

\section{RESULTS}

\section{In - lake}

Williams Lake had inverse thermal stratification under ice cover in March and December, and distinct thermal stratification in May, July, and August (fig. 5A). There was no distinct hypolimnion in July, and bottom temperatures were greater than $4^{\circ} \mathrm{C}$ in May, July, August, and October. Assuming that doubling the Secchi disk transparency depth is equal to the zone of light penetration in the lake, light reached the bottom of the lake at its deepest point in July and August.

Clinograde distributions of oxygen were observed on each sampling date of this survey ( $\mathrm{fig}$. 5B). However, oxygen was never completely absent from any part of the water column during this investigation. Oxygen was partially depleted under ice cover (fig. 5B), and near-anaerobic conditions existed at the lake bottom in March. Supersaturation of oxygen was 


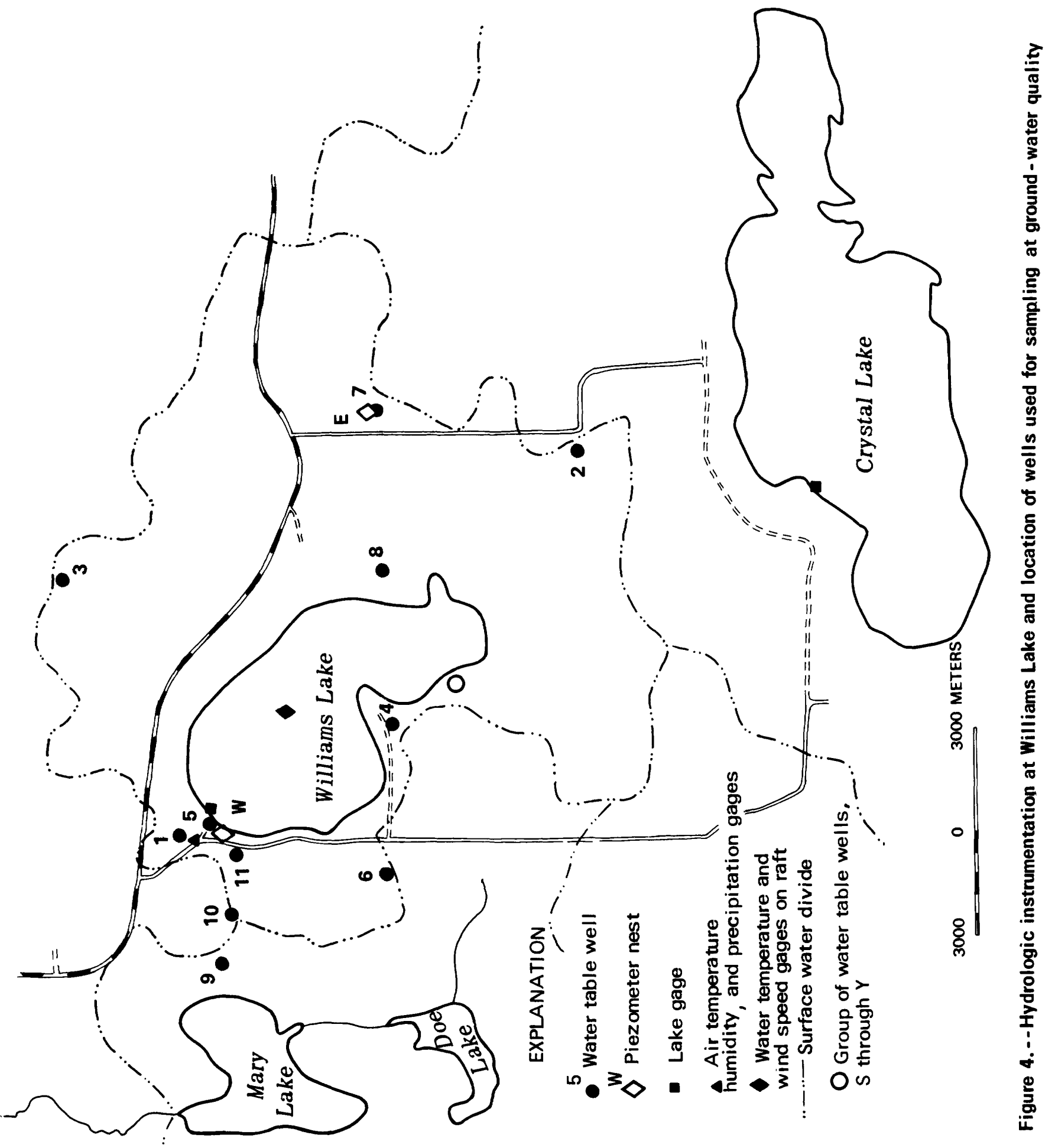




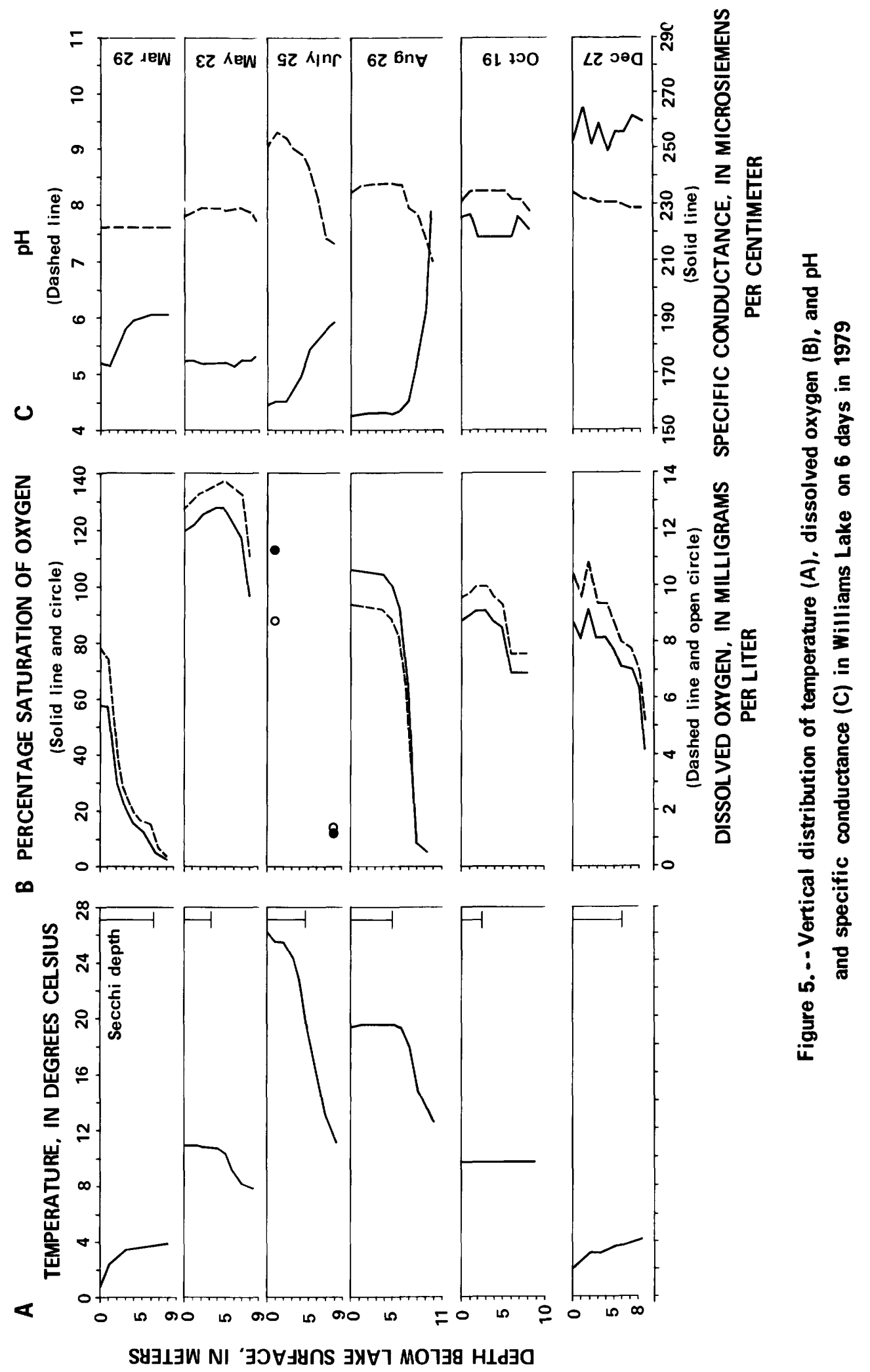


evident in May, July, and August and was probably related to photosynthetic activity in the lake.

Distinct clinograde distributions of $\mathrm{pH}$ were observed only in July and August (fig. 5C). The vertical distribution of specific conductance was inverse clinograde in March, July, and August (fig. 5C). Average specific conductance for the entire wafer column for all sampling dates was $194 \mu \mathrm{S} / \mathrm{cm}$, and the average calculated total dissolved solids concentration was $126 \mathrm{mg} / \mathrm{L}$ (milligrams per 1iter).

Calcium is the dominant cation and bicarbonate (alkalinity) is the dominant anion in Williams Lake (fig. 6). Kelts and Hsu (1979) state that in waters of $\mathrm{pH} 6.5$ to 8.5, the simplifying assumption of alkalinity equalling the bicarbonate concentration is valid. The conditions for this assumption were found to exist in Williams Lake during this study; independent determinations for silica, phosphorus, and nitrogen indicate they are present in quantities insufficient to influence alkalinity. In general, higher concentrations of iron and manganese were observed in the near-bottom samples compared to the near-surface samples (fig. 7), when the oxygen profiles for the lake were distinctly clinograde, and near-anaerobic conditions existed above the lake sediments. The average concentration of $\mathrm{SiO}_{2}$ for this study was $0.7 \mathrm{mg} / \mathrm{L}$; there was no consistent discernable difference between nearsurface and near-bottom samples (fig. 8).

For the dates that total phosphorus data are available, concentrations near the bottom were more than double the concentrations near the surface (fig. 9). Average total phosphorus concentrations were $0.008 \mathrm{mg} / \mathrm{L}$ at 1 meter below the surface, and $0.018 \mathrm{mg} / \mathrm{L}$ at 1 meter above the bottom. Kjeldahl nitrogen was the major component of total nitrogen for the sample dates. Differences between the near-bottom and near-surface nitrogen concentrations are not as distinct as those for total phosphorus. Average concentrations for total nitrogen components were $0.47 \mathrm{mg} / \mathrm{L}$ for $\mathrm{Kjeldahl}$ nitrogen as nitrogen, and $0.059 \mathrm{mg} / \mathrm{L}$ for nitrite plus nitrate as nitrogen. Based on all of the dates and depths for which total nitrogen (N) and total phosphorus (P) data were available, the N:P ratio for Williams Lake is $46: 1$ by weight.

Blue-green algae were the most numerous group of algae found in Williams Lake (fig. 10). Diatoms were most abundant in 0ctober, the only sampling date that the lake was truly isothermal. Phytoplankton genera found during the study are shown in table 2 .

Copepods were the most numerous group of zooplankton found in this survey (fig. 11). However, rotifers were more abundant than either copepods or cladocerans during the isothermal conditions observed in October. Zooplankton genera found during the study are shown in table 3 .

The average chlorophyll a concentration for the second half of the study was $4.18 \mathrm{mg} / \mathrm{m}^{3}$. The first few samples for chlorophy11 a analyses were 


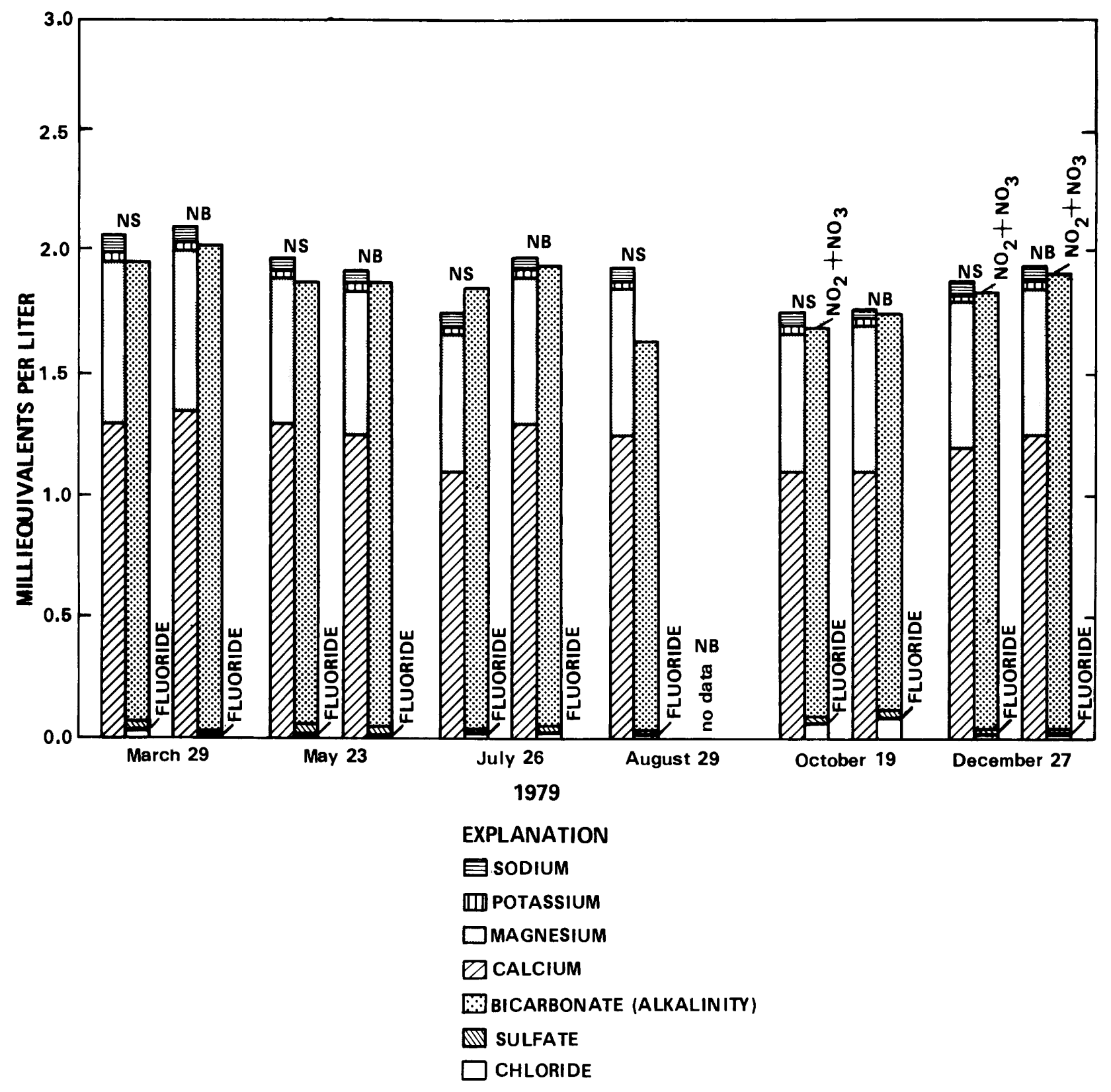

Figure 6. - - Major ion concentrations for near - surface and near-bottom samples of Williams Lake on 6 days in 1979 


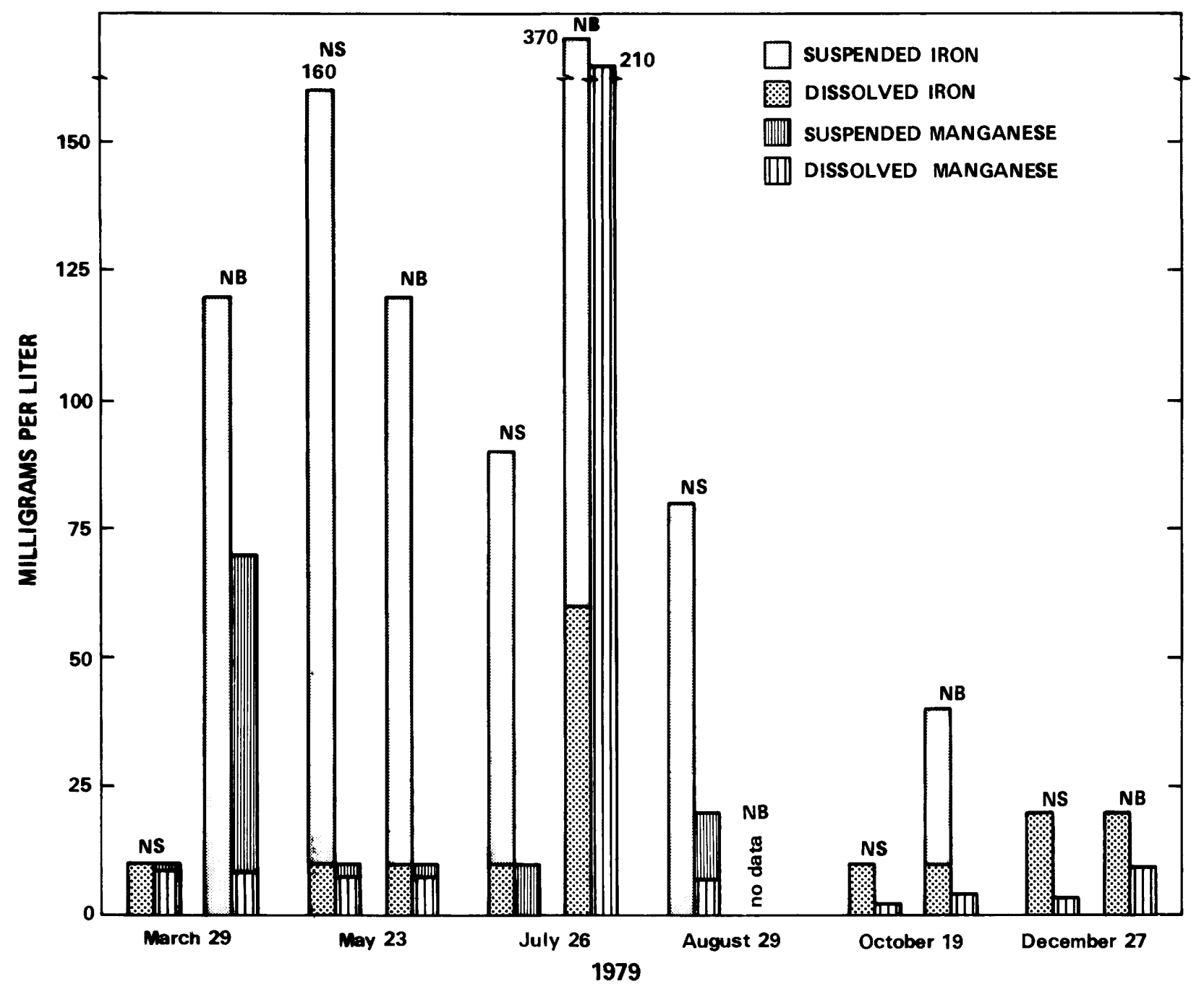

Figure 7. - - Iron and manganese concentrations for near - surface and near - bottom samples of Williams Lake on 6 days in 1979 


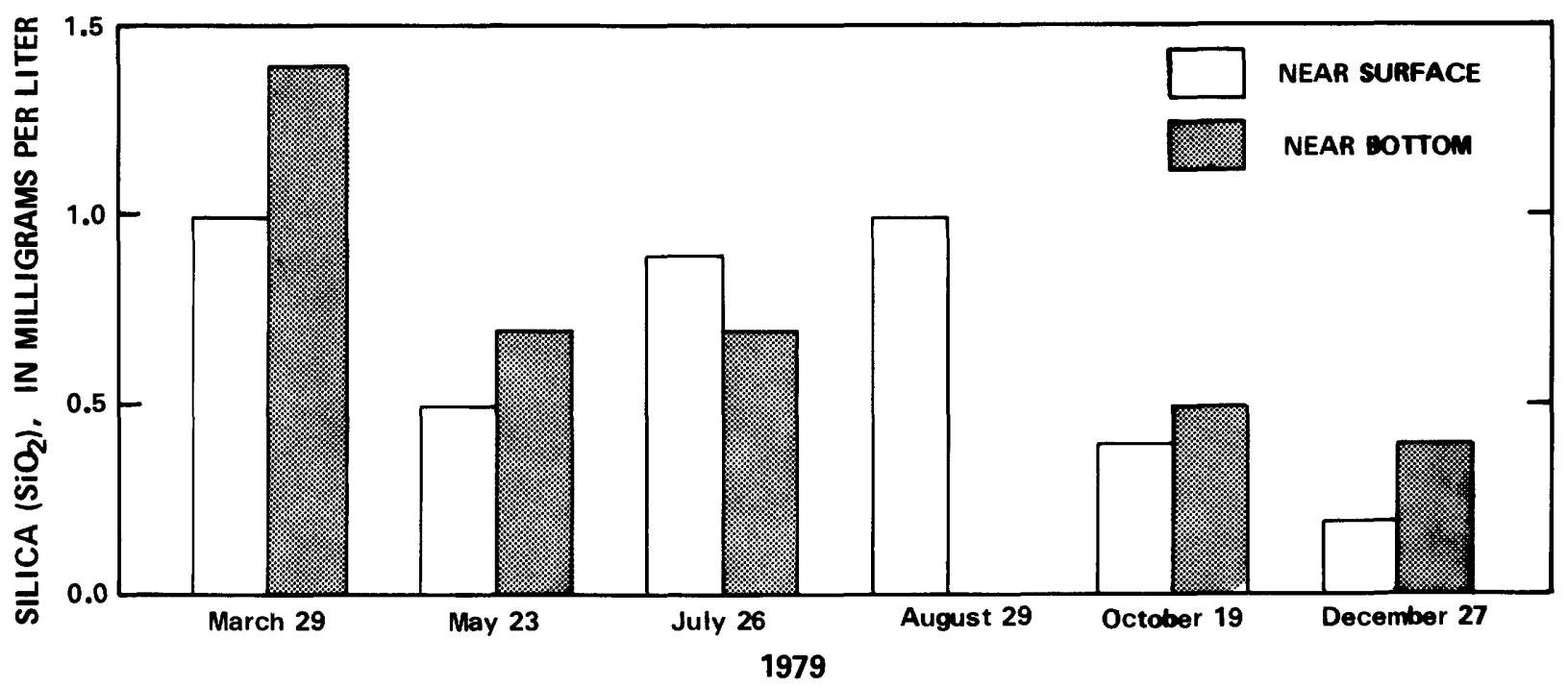

Figure 8. - - Near - surface and near - bottom concentrations of silica in Williams Lake on 6 days in 1979 

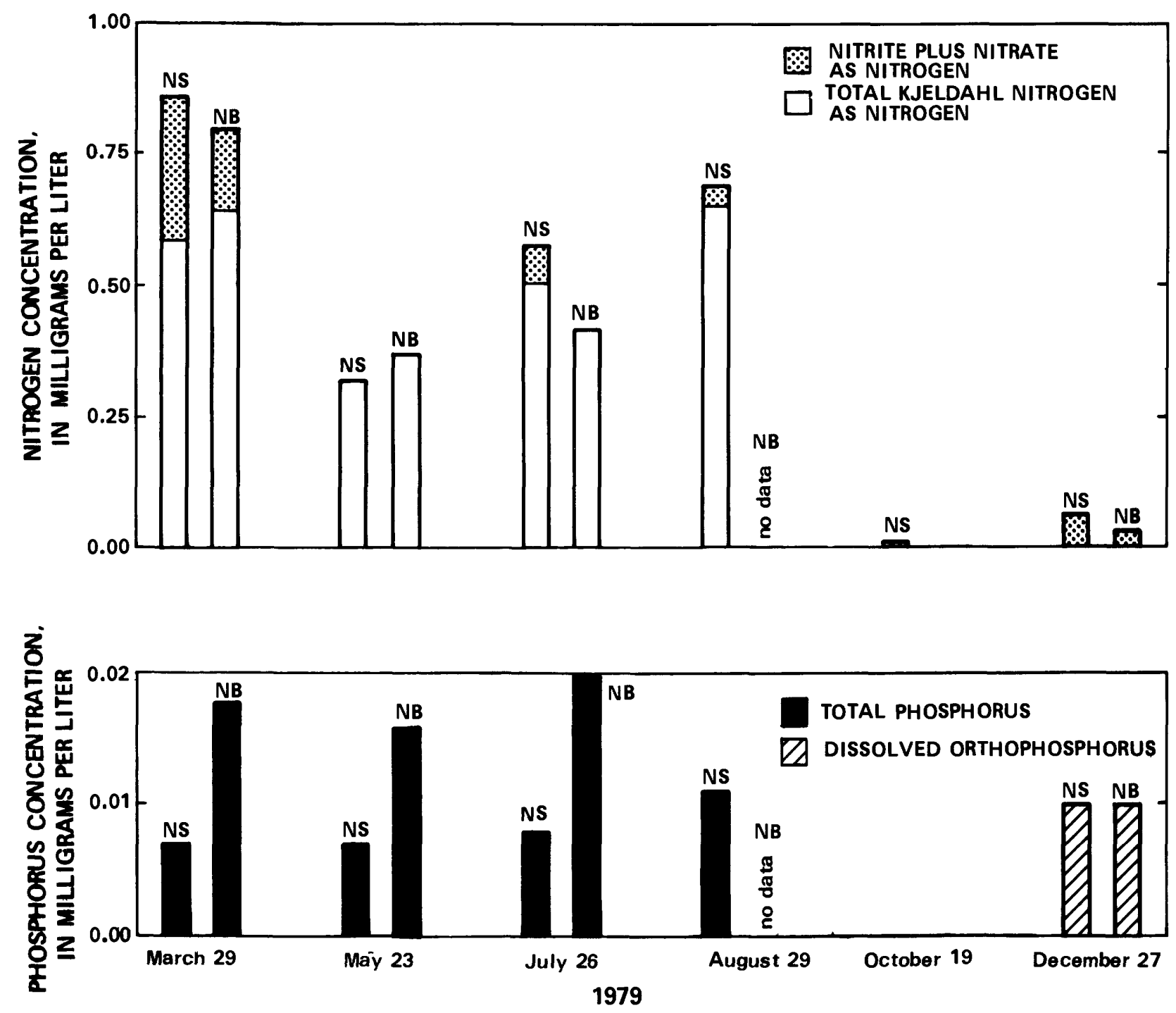

Figure 9. - - Near - surface and near-bottom concentrations for phosphorus and nitrogen in Williams Lake on 6 days in 1979. Analyses for total phosphorus and Kjeldahl nitrogen were not made for the October and December sampling dates 


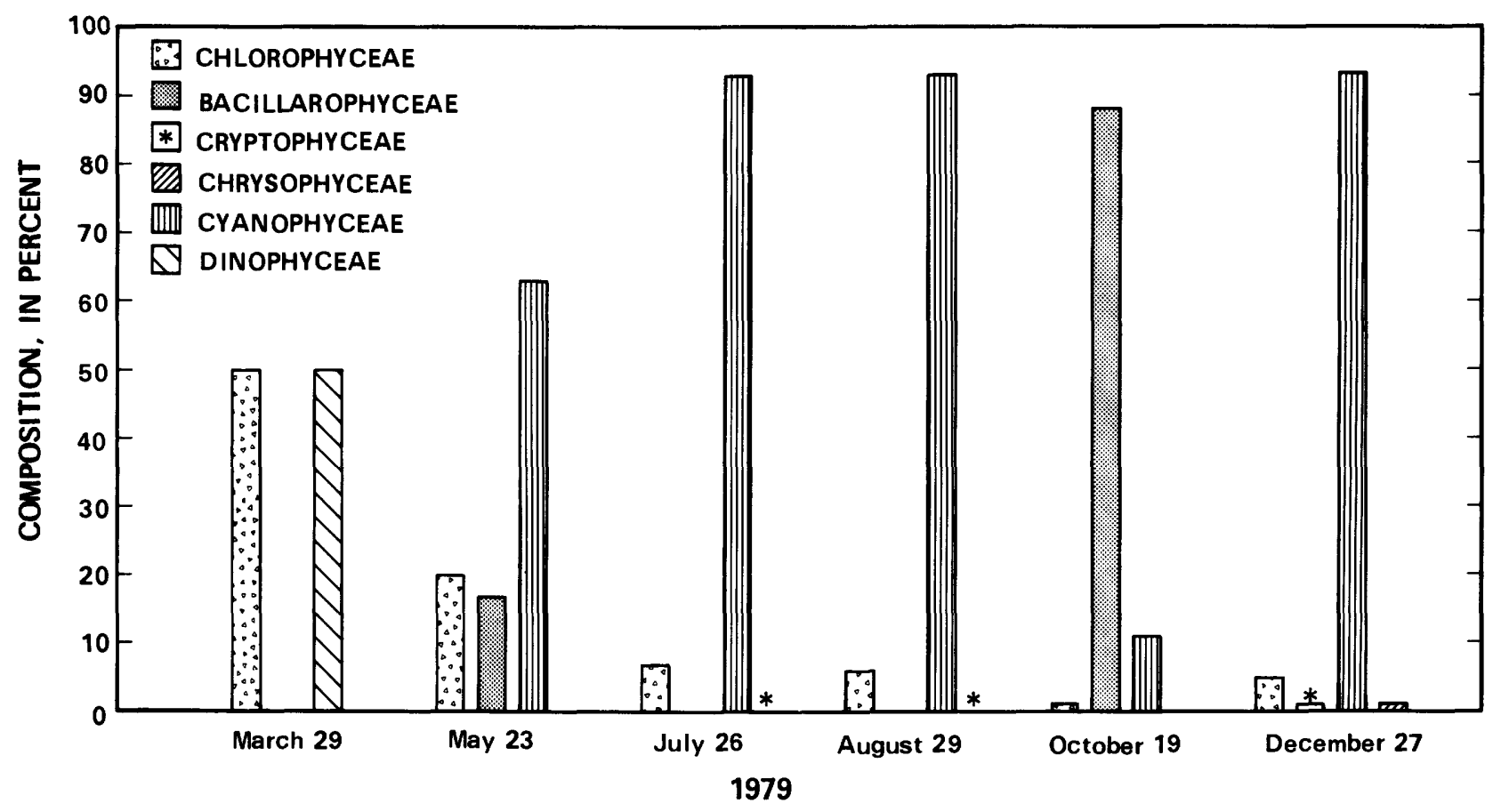

Figure 10. - - Percent composition of the phytoplankton community of Williams Lake on 6 days in 1979, based on cell counts 
Table 2. - - Phytoplankton genera found in Williams Lake, Minnesota, on 6 days in 1979

$$
\begin{gathered}
{[\mathrm{X}=\text { indicates genera comprising greater than } 10 \text { percent of total numbers }} \\
\text { on the sampling date; } /=\text { indicates present on sampling date }]
\end{gathered}
$$

Organism

Date of sampling I/

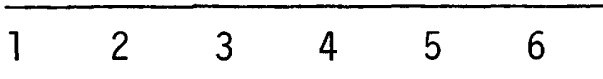

Chlorophyceae (greens):

Schroederia

oocystis

Scenedesmus

Elakatothrix

Gloeocystis

Tetraedron

Chlamydomonas

$\begin{array}{llll}x & 1 & 1 & \\ 1 & 1 & 1 \\ 1 & 1 & \\ & 1 & \\ 1 & 1 & \\ & 1 & \end{array}$

$x$

Bacillariophyceae (diatoms):

Cyclotelza

Melosira

Fragizlaria

Nitzschia

Asterionelza

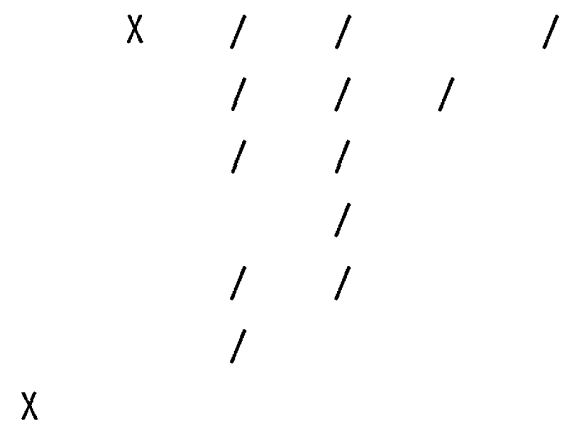


Table 2. - Phytoplankton genera found in Williams Lake, Minnesota, on 6 days in 1979 ( continued)

Organism

Date of samplingll

\begin{tabular}{|c|c|c|c|c|c|c|}
\hline \multirow{2}{*}{ urganism } & & & & & & \\
\hline & 1 & 2 & 3 & 4 & 5 & 6 \\
\hline oscizzatoria & & & / & $x$ & & $x$ \\
\hline Coccochloris & & & l & & & \\
\hline Gomphosphaeria & & & / & & & \\
\hline \multicolumn{7}{|c|}{ Cryptophyceae (cryptomonads): } \\
\hline Cryptomonas & & & / & / & & \\
\hline Chroomonas & & & I & & & \\
\hline \multicolumn{7}{|c|}{ Dinophyceae (dinoflagellates): } \\
\hline Ceratium & & & / & & & \\
\hline Glenodinium & $x$ & & & & & \\
\hline
\end{tabular}
1/Sampling day - (1) March 29, (2) May 23, (3) July 26, (4) August 29, (5) October 19, and (6) December 27

destroyed during processing; therefore chlorophyll a data are available for only the latter half of the study. The number of phytoplankton varied widely, from $26 \mathrm{cells} / \mathrm{mL}$ (cells per milliliter) in March to 88,000 cells $/ \mathrm{mL}$ in July. Zooplankton numbers ranged from 3,375 organisms $/ \mathrm{m}^{3}$ (organisms per cubic meter) in December to 21,900 organisms $/ \mathrm{m}^{3}$ in May, based on the average of the two replicate samples. Algal biomass, as measured by chlorophyll $\alpha$, and total numbers for both phytoplankton and zooplanton are shown in figure 12 .

A partial survey of macrophytes indicated that the predominant emergent plants are Nymphaea species. The main submersed macrophytes are Chara species and three species of Potamogeton. All of these macrophytes are generally confined to zones along the western shore and in the bogs at the southeast end of the lake. The southeast bay contained a dense growth of Nymphaea species, covering 70-80 percent of the water surface in the bay. This bay also had a sparse population of Equisetum species.

\section{Lake - sediment mineralogy}

Quartz is the most abundant mineral in nearly all samples of Williams Lake sediments. No carbonates were identified in the gyttja. In the 


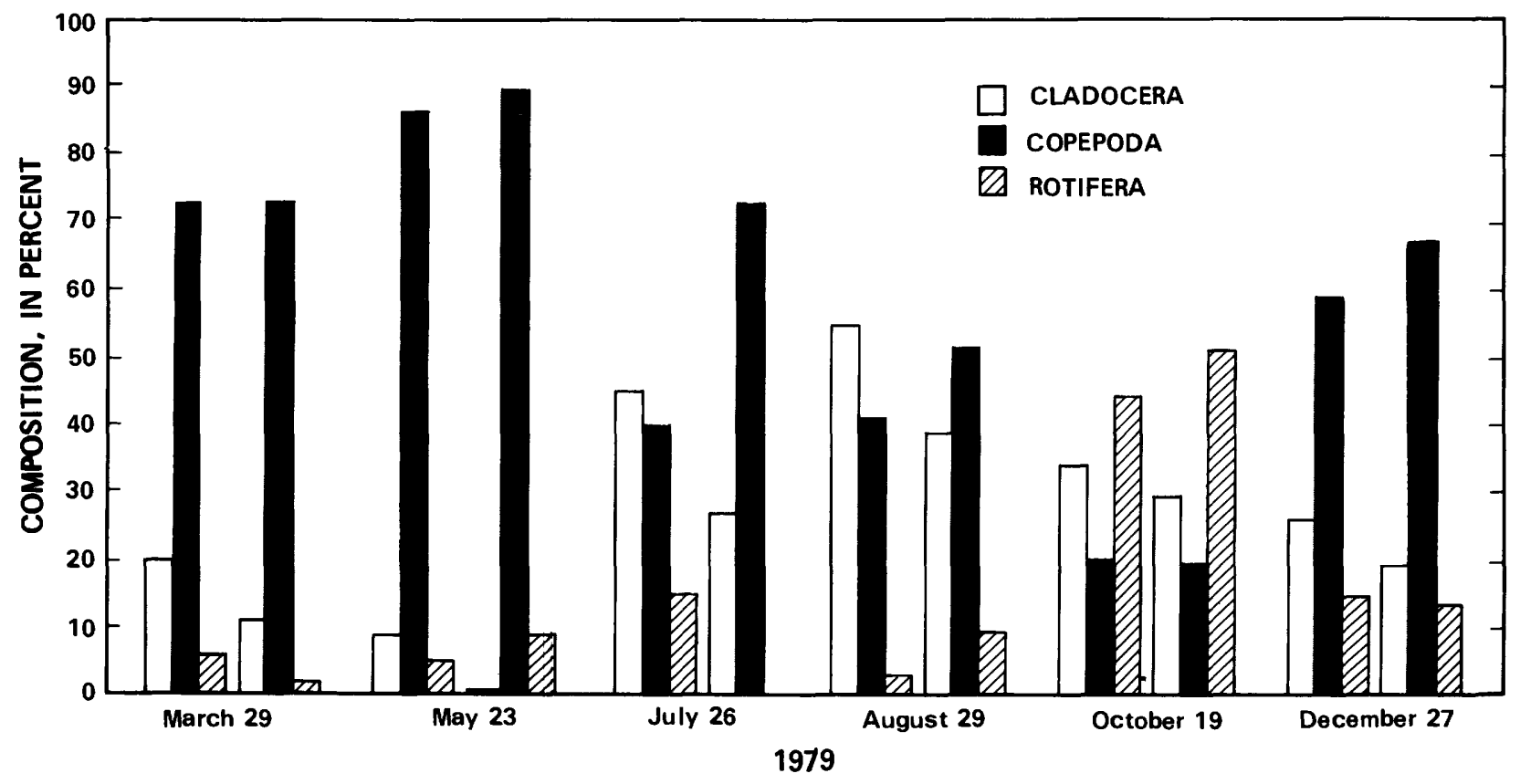

Figure 11. - Percent composition of the zooplankton community of Williams Lake on 6 days in 1979, based on counts from two replicate vertical hauls 
Table 3. - - Zooplankton genera found in Williams Lake, Minnesota, on 6 days in 1979

$$
\begin{gathered}
{[\mathrm{X}=\text { indicates genera comprising greater than } 15 \text { percent of total numbers }} \\
\text { on the sampling date; } /=\text { indicates present on sampling date }]
\end{gathered}
$$

Organism

Date of sampling $1 /$

$\begin{array}{lllll}12 & 3 & 4 & 5 & 6\end{array}$

\section{Cladocera}

Daphnia

Ceriodaphnia

Bosmina

AZona

Chydoms

Rotifera

Kellicottia

Kerateiza

Polyarthra

Asplanchna

Unknown Rotifera

Copepoda

Diaptomus

Unknown adult cyclopoid

$\begin{array}{cccccc}1 & 1 & x & x & x & x \\ 1 & 1 & 1 & 1 & & 1 \\ & 1 & & & & \\ 1 & 1 & x & x & 1\end{array}$




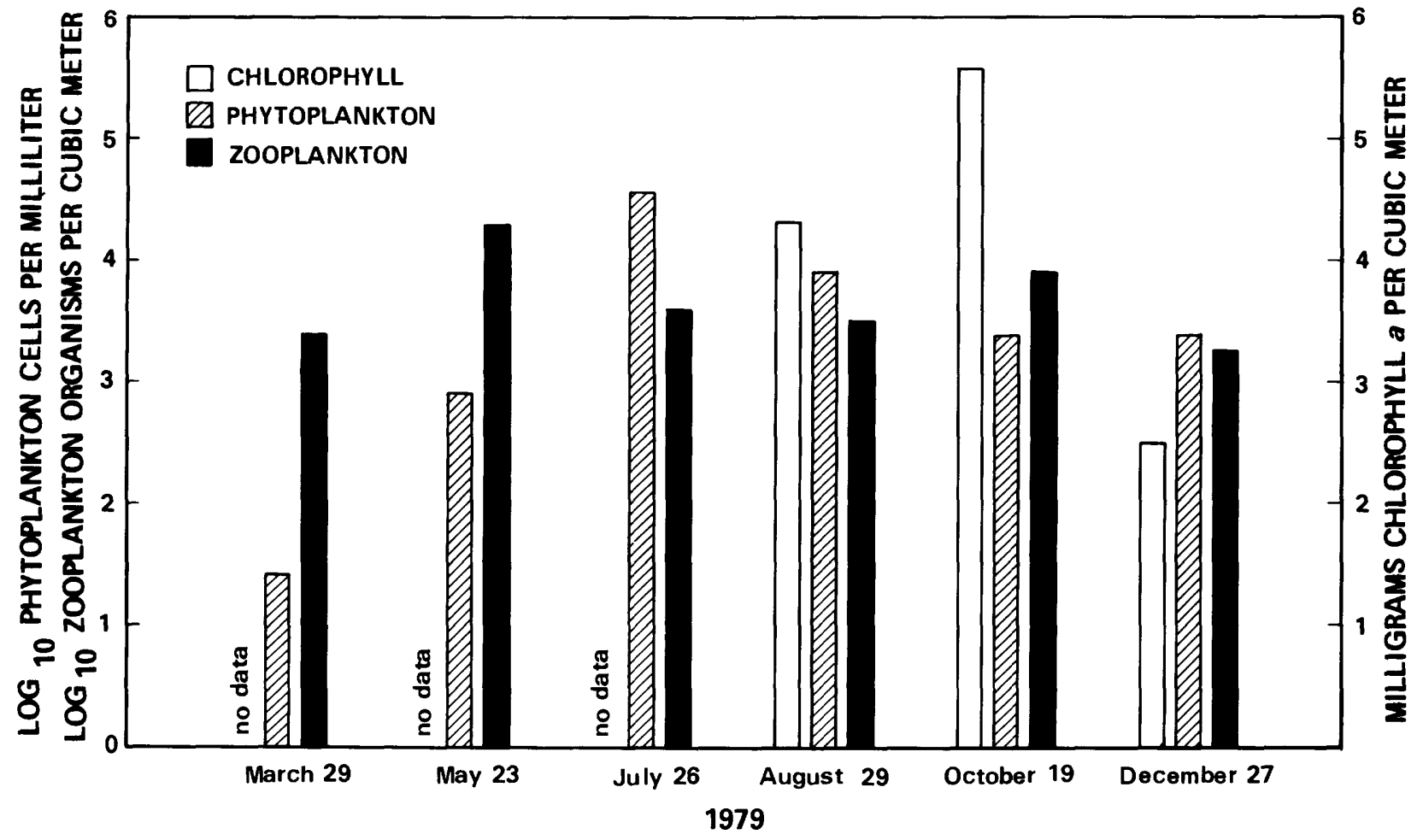

Figure 12. - - Phytoplankton numbers, chlorophyll concentrations, and zooplankton numbers for Williams Lake on 6 days in 1979 
A detailed discussion of the geochemical lake-ground-water system that leads to the deposition of this calcite deposit is presented by Groschen (1981). Lithologic descriptions of the sediment cores that were subsampled for mineralogical analysis are given in table 4. Semi-quantitative mineral abundances measured in randomly-mounted, X-rayed powder samples are given in table 5 .

Dolomite is present in many of the lake-sediment samples. The samples from core 7 that were analyzed were taken from the glacial drift beneath the lake sediments. In these deposits, dolomite is equal to or exceeds the amount of calcite, which is probably due to the relative abundances of these minerals in the source rocks of the glacial deposits in the watershed. The quartz, calcite (not associated with marl), dolomite, albite, potassium feldspar, and amphibole present in the lake sediments also are probably derived from the watershed.

Kaolinite and chlorite are the dominant clay minerals, but mixed-layer clays also are present. Clay minerals were determined by oriented X-ray techniques on the size fraction of the samples less than $1 \mu \mathrm{m}$ (Jones and Bowser, 1979). Calcite was identified in this size fraction only in the inorganic lake-sediment samples. The glacial drift sample from core 7 apparently contains no calcite particles smaller than $1 \mu \mathrm{m}$.

\section{Ground water}

According to Siegel and Winter (1981), Williams Lake has about equal amounts of ground-water inflow and outflow. Their study was of only a 3month, late-summer period, during which ground water constituted about 12 percent of total inflow and outflow. On an annual basis it is estimated that ground-water inflow and outflow is probably between 10 and 20 percent of the total water budget.

Field analyses (tables 6 and 7) and laboratory analytical data (table 8) show that ground water near Williams Lake is of the calcium bicarbonate type. Laboratory data are for ground water taken from piezometers $W L N-40, W L N-70$, WLN-100, and $W L N-130$ of nest $W$ (fig. 4). These piezometers are completed in the upper outwash sand which underlies the lake basin. The three ions: $\mathrm{Ca}^{+2}$ (calcium), $\mathrm{Mg}^{+2}$ (magnesium), and $\mathrm{HCO}_{3}^{-}$(bicarbonate) constitute 95 to 98 percent of the total ionic concentration, in equivalents.

Mean temperature of the ground water in the study area is $9.2{ }^{\circ} \mathrm{C}$. Specific conductance ranges from 250 to $505 \mu \mathrm{S} / \mathrm{cm}$. The lower conductance values are from zones where lake water seeps to ground water, for example at well 4 (fig. 4). The $\mathrm{pH}$ of ground water ranges from 7.25 to 8.10. Calcium concentrations range from 40 to $92 \mathrm{mg} / \mathrm{L}$, and generally increase with increasing specific conductance. Magnesium concentrations range from 6.7 to $18.0 \mathrm{mg} / \mathrm{L}$, but have no clear trend with respect to specific conductance. Alkalinity (expressed as $\mathrm{mg} / \mathrm{L}$ bicarbonate) ranges from 170 to $385 \mathrm{mg} / \mathrm{L}$; it shows a trend similar to calcium with respect to specific conductance. 
Table 4. - - Lithologic description of lake - sediment cores

\begin{tabular}{|c|c|c|}
\hline Core No. $1 /$ & $\begin{array}{l}\text { Depth below } \\
\text { lake surface, } \\
\text { in meters }\end{array}$ & Description \\
\hline \multirow[t]{4}{*}{4} & $0 \quad-9.80$ & Water. \\
\hline & $9.80-13.70$ & Gyttja. \\
\hline & $13.70-14.20$ & Silt and clay. \\
\hline & $14.20-15.20$ & Silt. \\
\hline \multirow[t]{4}{*}{6} & $0-2.00$ & Water. \\
\hline & $2.00-2.30$ & Loose organic floc. \\
\hline & $2.30-3.50$ & $\begin{array}{l}\text { Light-colored marly sediment, some } \\
\text { organic sediment and plant fragments } \\
\text { (?) scattered throughout. }\end{array}$ \\
\hline & $3.50-3.55$ & Sand, medium-coarse (glacial drift). \\
\hline \multirow[t]{12}{*}{7} & $0-4.50$ & Water. \\
\hline & $4.50-5.40$ & Gyttja. \\
\hline & $5.40-5.50$ & Gyttja, contains plant fragments. \\
\hline & $5.50-5.62$ & $\begin{aligned} \text { Marl (?) contains plant fragments } \\
\text { lake sediments. } \uparrow\end{aligned}$ \\
\hline & & glacial drift. $\downarrow$ \\
\hline & $5.62-5.65$ & Gravel. \\
\hline & $5.65-5.67$ & Silt, uniform. \\
\hline & $5.67-5.72$ & Sand, fine-medium. \\
\hline & $5.72-5.77$ & Silt, sandy. \\
\hline & $5.77-5.80$ & Sand, medium-coarse. \\
\hline & $5.80-5.97$ & $\begin{array}{l}\text { Silt, scattered fine sand, has } \\
\text { banded appearance. }\end{array}$ \\
\hline & $5.97-6.50$ & $\begin{array}{l}\text { Sand, medium-coarse, scattered fine- } \\
\text { medium gravel (glacial drift). }\end{array}$ \\
\hline
\end{tabular}

1/Core 2 was not described in the field; cores 1,3 , and 5 were not subsampled for mineralogic analysis. 
Table 5. - - Bulk - mineral composition of selected sections of Williams Lake sediment cores

$$
\begin{array}{r}
{[Q=\text { quartz; } C=\text { calcite } \quad D=\text { dolomite; } A b=\text { albite; } K=\text { potassium feldspar; }} \\
A m=\text { amphibole; all analyses by } B . F . \text { Jones }]
\end{array}
$$

\begin{tabular}{|c|c|c|c|}
\hline $\begin{array}{l}\text { Core } \\
\text { number } 1 /\end{array}$ & $\begin{array}{l}\text { Depth below } \\
\text { ice surface, } \\
\text { in meters }\end{array}$ & $\begin{array}{l}\text { Description of core } \\
\text { section? }\end{array}$ & $\begin{array}{c}\text { Relative bulk mineral } \\
\text { abundances }\end{array}$ \\
\hline
\end{tabular}

\begin{tabular}{|c|c|c|c|}
\hline \multirow[t]{5}{*}{2} & $10.50-11.00^{3 /}$ & $\begin{array}{c}\text { Black-brown gelatinous } \\
\text { gyttja (Holocene). }\end{array}$ & $Q \gg A] \gg K$ (no carbonates). \\
\hline & $12.05-12.10$ & -- do -- & $Q \gg \mathrm{Al} \gg \gg \mathrm{K}$ (no carbonates). \\
\hline & $13.20-13.25$ & $\begin{array}{l}\text { Dark silt (Holocene- } \\
\text { Pleistocene?). }\end{array}$ & $Q>C>D>A l>K$. \\
\hline & $14.10-14.15 \frac{31}{}$ & $\begin{array}{l}\text { Light gray silt with } \\
\text { some sand (Pleistocene). }\end{array}$ & $Q=C>D=A l \gg K \gg$ Am. \\
\hline & $15.00-15.05^{3 /}$ & -- do -- & $Q=C \gg D=A l \gg K \gg>A m$. \\
\hline 4 & $\begin{array}{l}13.70-13.75 \frac{3 /}{1} \\
14.20-14.25 \frac{31}{}\end{array}$ & $\underline{21}$ & $\begin{array}{l}Q=C>D>A l>K . \\
Q=C>D>A I>K .\end{array}$ \\
\hline 6 & $3.00-3.05$ & $\underline{21}$ & $C>Q>>D$ \\
\hline 7 & $\begin{array}{l}5.97-6.00 \\
6.42-6.4531\end{array}$ & $\underline{21}$ & $\begin{array}{l}Q>A 1>C=D>K . \\
Q>A 1>D>C .\end{array}$ \\
\hline
\end{tabular}

$1 /$ Cores 1,3 , and 5 were not subsampled for mineralogic analys is. 2/See table 4 for lithologic descriptions of lake-sediment cores for cores 4,6 , and 7 .

3/ These samples also were analyzed for minerals in the $<l-\mu m$ size fraction in oriented mounts. 


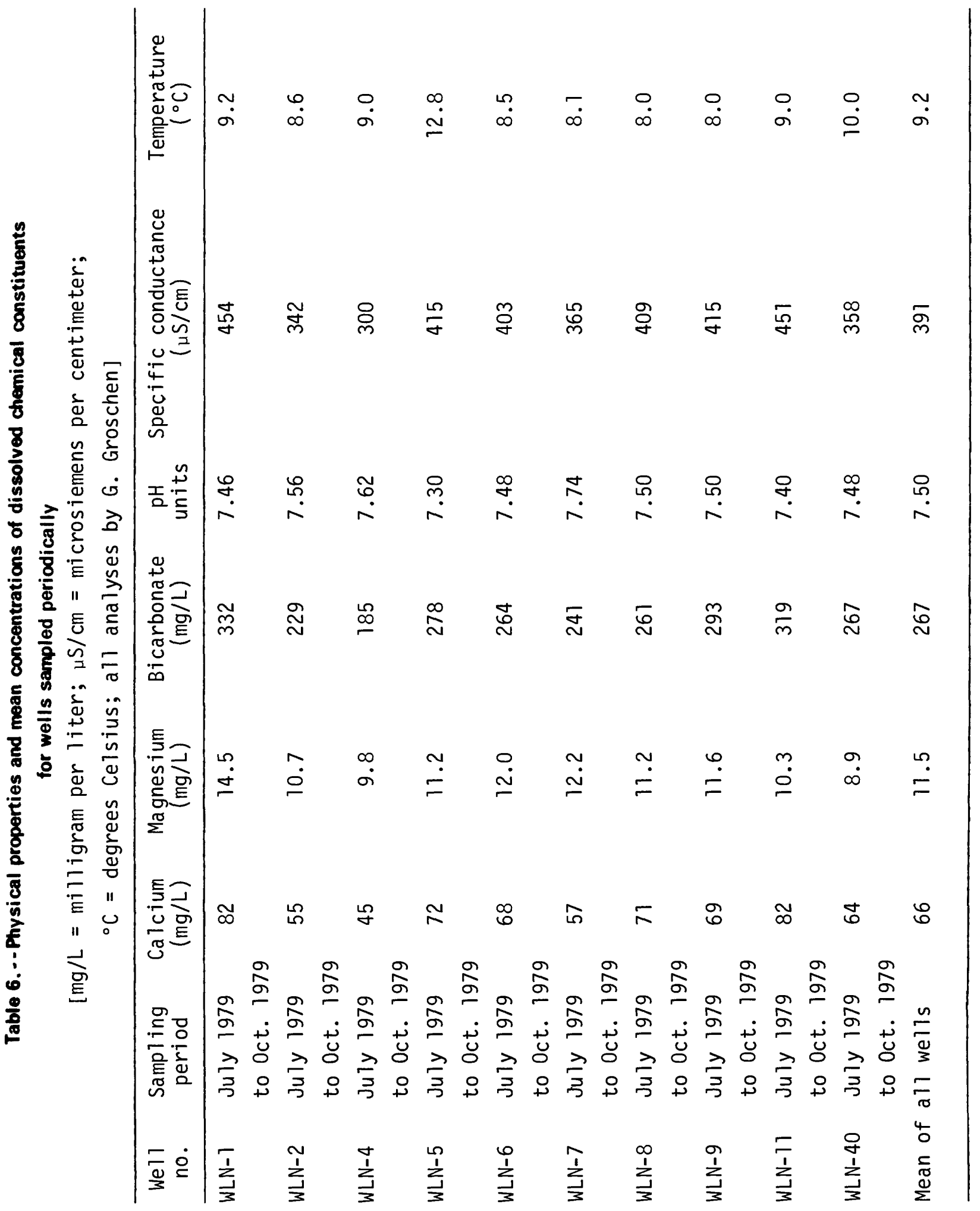




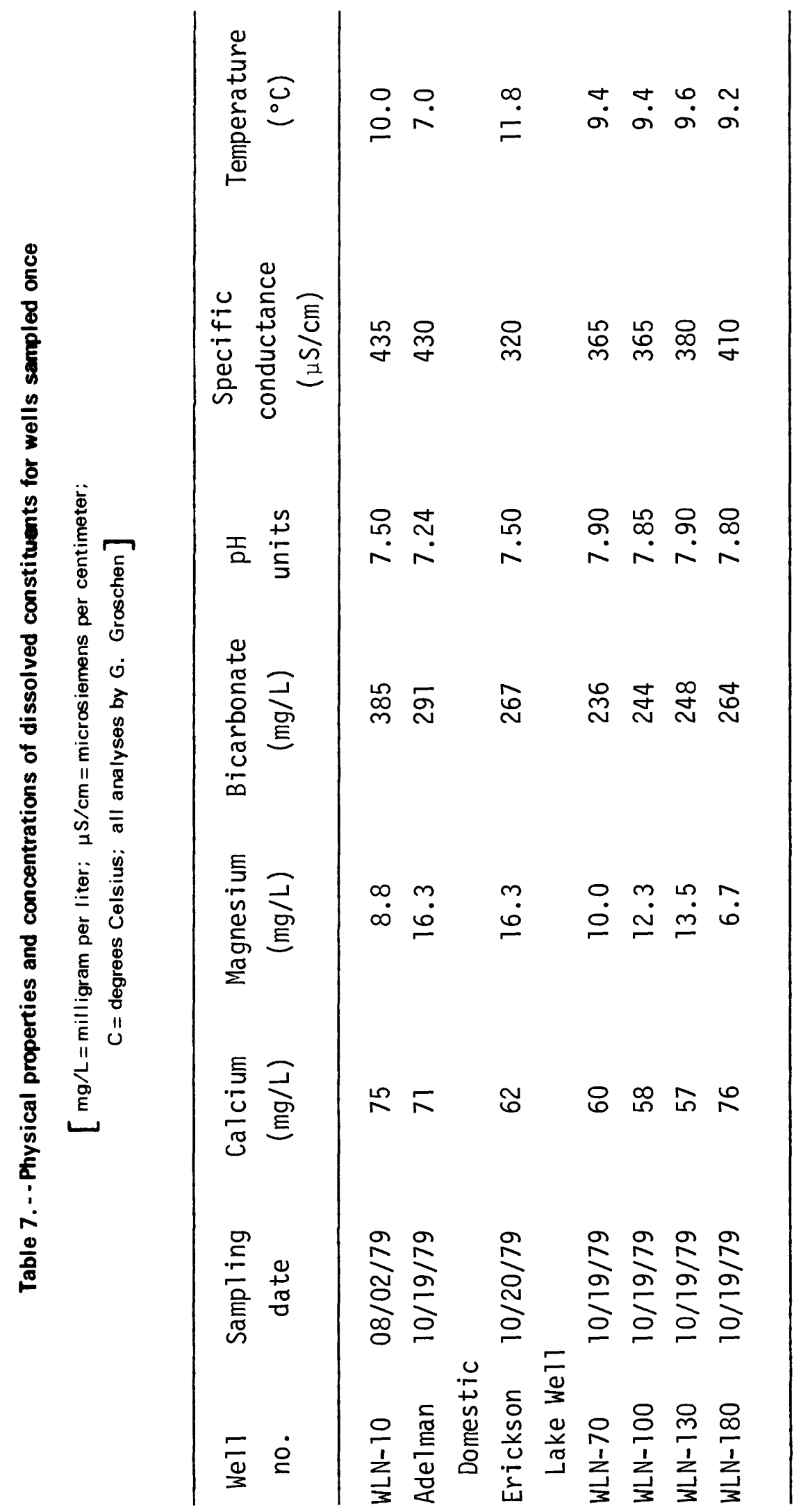




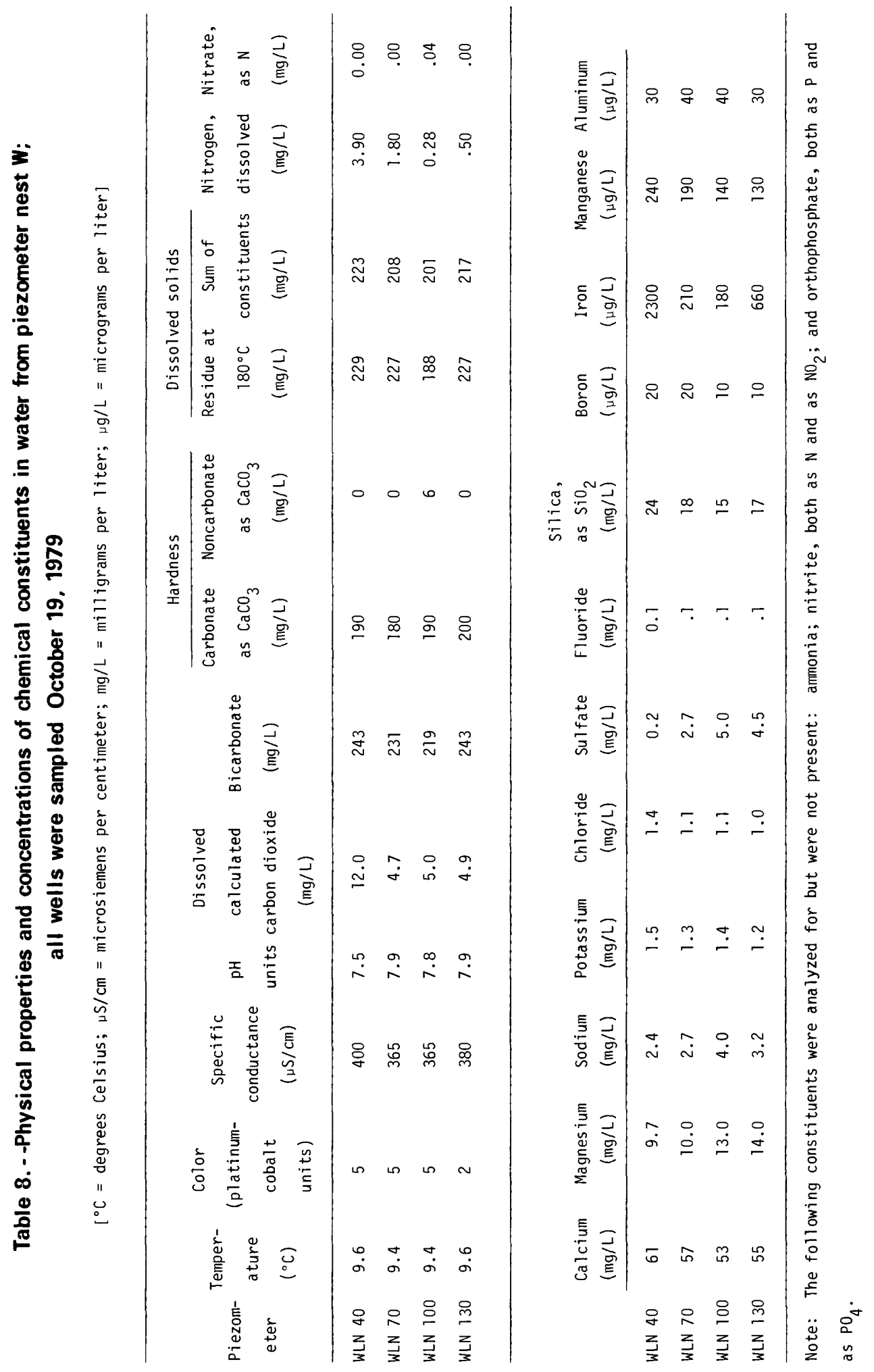


Concentrations of the major dissolved species in ground water taken from the four piezometers of nest $W$ on October 19, 1979, are compared with lake water sampled October 18, 1979 (fig. 13A). Iron and manganese concentrations in these same samples are shown in figure 13B. The Eh and $\mathrm{pH}$ conditions in the lake may exert more control on calcium, alkalinity, iron, and manganese than dilution by rain and snow. The Eh and $\mathrm{pH}$ conditions in the lake are greatly different than the conditions of the ground-water environment. The effect of this difference can be seen in untreated filtered water from WLN-40 that was left in a polyethylene bottle--red precipitate formed in the bottle after a few days. A similar precipitate also has been reported in water from a shallow domestic well nearby. The high iron and manganese concentrations shown in figure 13B as well as the presence of $\mathrm{H}_{2} \mathrm{~S}$ gas noted during pumping of the piezometers may be due to reducing conditions (low $\mathrm{Eh}$ ) in the ground-water system.

Reduced iron and manganese in solution will oxidize upon exposure to atmospheric oxygen (high Eh) and precipitate out of solution. Preliminary WATEQF (a FORTRAN IV computer program for calculating chemical equilibrium of natural waters) (Plummer and others, 1976) computations show that ground water is theoretically in equilibrium with a high partial pressure of $\mathrm{CO}_{2}$ and with calcite. Water withdrawn from a piezometer at Williams Lake most likely will release $\mathrm{CO}_{2}$, which increases the $\mathrm{pH}$, and thus creates conditions for calcite precipitation. The red precipitate from the ground water from piezometer WLN-40 is probably a mixture of amorphous iron hydroxide and calcium carbonate.

A similar change in Eh and $\mathrm{pH}$ occurs when ground-water discharges into the lake. Assuming the water discharging into the lake is similar to that taken from piezometer WLN-40, there is probably a loss of dissolved calcium, alkalinity, iron, and manganese from solution, which may explain the differences between ground water and lake water shown in figures $13 \mathrm{~A}$ and $13 \mathrm{~B}$.

In the Williams Lake system, solubility of magnesium is not as susceptible to $\mathrm{pH}$ controls as are calcium, alkalinity, iron, and manganese, nor as susceptible to Eh controls as are iron and manganese. Comparison of the concentrations of magnesium in ground water and lake water yields a rough estimate of the amount of dilution affecting all ions. The concentration of magnesium in lake water is 61 percent of the average $(11.6 \mathrm{mg} / \mathrm{L})$ concentration of magnesium in ground water from the four piezometers. Concentration of calcium in lake water is 39 percent of the four-piezometer average (56 mg/L). Alkalinity of the lake water is 42 percent of average ground-water concentrations $(190 \mathrm{mg} / \mathrm{L})$. If magnesium is affected only by dilution, changes in $\mathrm{pH}$ and partial pressure of $\mathrm{CO}_{2}$ should account for the additional 19 to 21 percent reduction in calcium and alkalinity concentrations.

This is shown more convincingly by the differences in iron and manganese concentrations between ground water and lake water. Concentration of iron in lake water is only 1 percent of the average concentration in ground water from the four piezometers. Concentration of manganese in lake 


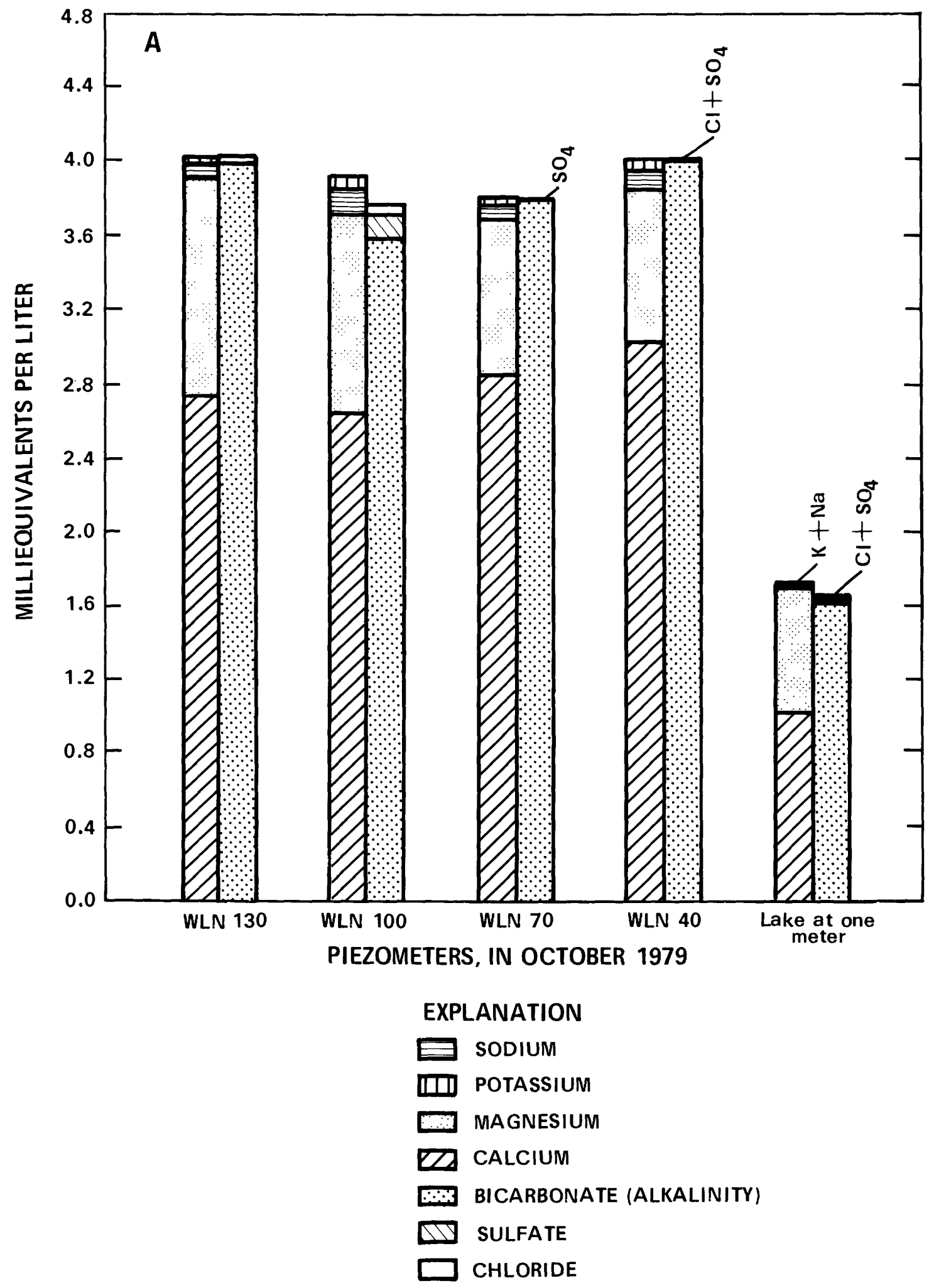

Figure 13. (A) - Chemical characteristics of ground - water for selected piezometers of nest W and for lake - water at 1 meter depth, October 19, 1979: Major ion concentrations 


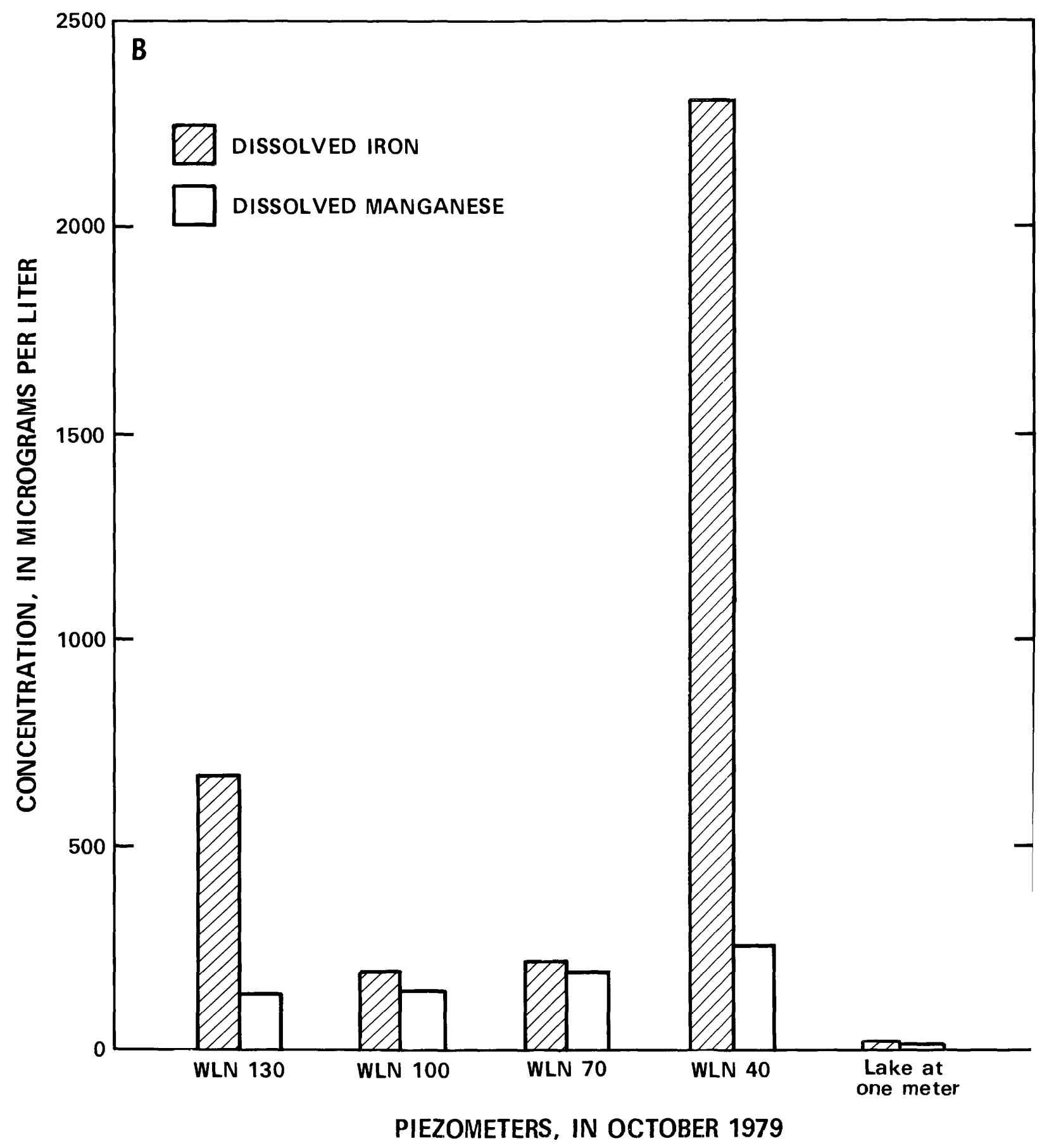

Figure 13.(B) - - Chemical characteristics of ground water for selected piezometers of nest $W$ and for lake - water at 1 meter depth, October 19, 1979:

dissolved iron and manganese concentrations 
water is 17 percent of the average concentration in ground water from the four piezometers. The oxidizing conditions (high Eh) in lake water probably cause the iron and manganese to precipitate.

Sulfate concentrations are low in the ground water sampled; most are less than $5 \mathrm{mg} / \mathrm{L}$. The lower limit of the analytical procedure used to determine sulfate in Williams Lake water samples is $5 \mathrm{mg} / \mathrm{L}$ (Friedman and Beetem, 1980), therefore the accuracy of those sulfate determinations less than $5 \mathrm{mg} / \mathrm{L}$ is uncertain. Chloride is present in concentrations less than $1.5 \mathrm{mg} / \mathrm{L}$. The major source of these two anions may be the atmosphere. Sodium concentration also is low: less than $5.0 \mathrm{mg} / \mathrm{L}$; potassium concentration also is low: less than $2.0 \mathrm{mg} / \mathrm{L}$.

No significant changes in the chemistry of ground water were observed during July through October 1979. A series of water-table wells on the southwestern shore were sampled twice in 0ctober. Except for well Y, ground water from these wells showed little variation between the two sampling dates. However, concentrations of calcium and bicarbonate ions increase away from the lake along a flow path from the lake to well W (fig. 14). Concentrations of calcium, magnesium, and bicarbonate in lake water and ground water from WLN-8 are included in figure 14 for comparison. WLN-8 water is considered representative of ground water flowing into the lake on the eastern shore.

Well $\mathrm{Y}$ is located near a wetland at the west end of the series of wells shown in figure 14. This wetland might be related to the water-table mound determined by water-level measurements in wells $\mathrm{S}$ through $\mathrm{Y}$. Percolating rain water probably dilutes ground water near the wetland in the vicinity of wells $\mathrm{Y}$ and $\mathrm{X}$. Recent theoretical modeling studies by Winter indicate the most favorable locations for growth of water-table mounds; hence, ground-water recharge, is immediately adjacent to surface-water bodies. The large decrease in concentrations of calcium, magnesium, and bicarbonate in water from well Y on October 20, 1979 can probably be attributed to the $19 \mathrm{~mm}$ (millimeters) of precipitation on October 18, 1979.

Water seeping from the lake into the ground-water-flow system must come to equilibrium with the geochemical environment by dissolving carbonate minerals in the outwash sand. Based on WATEQF calculations, dilution of ground water by either infiltrating rain or lake water also would cause carbonate dissolution to attain equilibrium. The increase of concentrations of calcium and bicarbonate with distance from shore indicates dissolution of carbonate minerals to attain equilibrium occurs in the zone of seepage from the lake.

\section{DISCUSSION}

According to the criteria of Hutchinson (1957), Williams Lake is dimictic. Marked thermal stratification was observed under ice cover and in the summer. Temperatures greater than $24^{\circ} \mathrm{C}$ (degrees Celsius) were observed above $3.5 \mathrm{~m}$ in July, due in part to the transparency of the water 


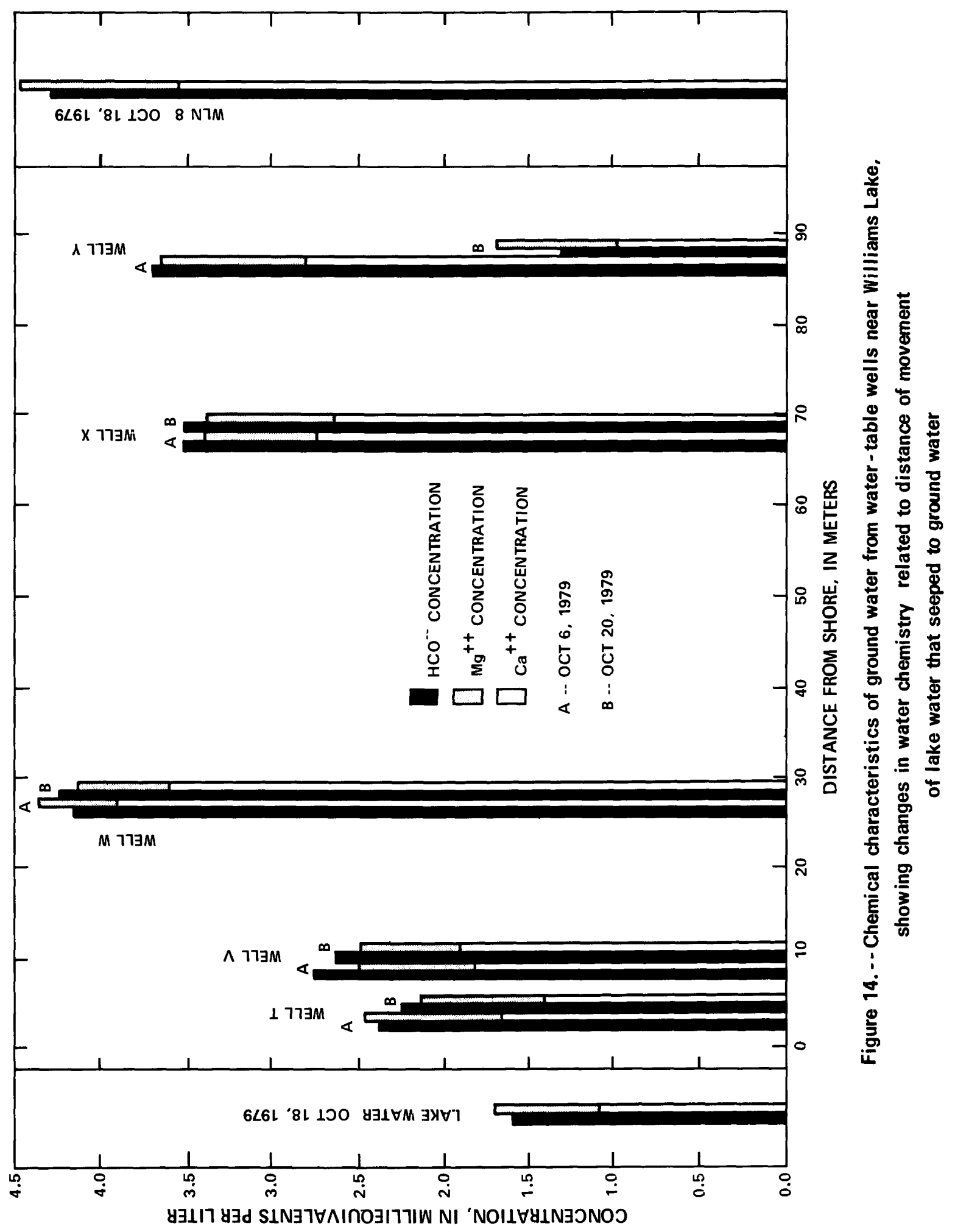


in Williams Lake. Secchi-disk transparency values indicate light penetrates to the bottom of the lake. This facilitates the growth of the lake's abundant submersed and emergent macrophytes. The depth of light penetration may also account for the slight oxygen maximum observed in May in conjunction with either the phytoplankton or macrophyte communities. Hutchinson (1957) has indicated that oxygen maxima involving supersaturated conditions are due to photosynthetic activity.

The concentration of major cations and anions in Williams Lake is somewhat higher than the world freshwater average reported by Livingstone (1963). The lake is similar to other lakes of northern and northeastern Minnesota classified by Tarapchak (1973), because water chemistry of the lake is dominated by calcium and bicarbonate ions. The major cation of the water chemistry of the contiguous ground-water system is also calcium; the major anion is bicarbonate. The importance of calcium and bicarbonate is probably a function of the composition of the glacial drift near the lake, which includes calcite and dolomite. The low concentrations of sulfate, chloride, sodium, and potassium in the lake and the contiguous ground-water system suggest the major source of these ions is from the atmosphere. Gorham (1961) has indicated the atmosphere can act as a source for chloride, sulfate, and sodium. Concentrations of these ions in the lake and its contiguous watershed were similar to values found in atmospheric precipitation by Garrels and MacKenzie (1971) and Likens (1976).

Williams Lake has no surface-water inlet or outlet. The major-ion data indicate that ground-water and not atmospheric exchange is primarily responsible for the ionic composition of Williams Lake, based on comparison between the relative differences in the ionic composition of the lake and the contiguous ground-water system. Similar comparisons between the ionic composition of lake water and water taken from water-table wells were made in the Trout Lake region of Wisconsin (Fries, 1938). Fries used those data to indicate that lakes with no surface inlet or outlet interacted with the local ground-water system.

Mortimer (1941, 1942) demonstrated that iron and manganese are mobilized from sediments to overlying water under near-anaerobic and anaerobic conditions. This process is a possible explanation for the higher concentrations of dissolved iron and manganese present in the July near-bottom sample compared to the near-surface sample, because nearly anaerobic conditions existed at $7 \mathrm{~m}$. Although the mechanism which facilitates mobilization of iron from the sediments described by Mortimer can also account for an increase in phosphorus concentrations in the water above the sediments, it is not clear that this is occurring in Williams Lake. There is a distinct difference between near-surface and near-bottom total phosphorus concentrations when conditions are nearly anaerobic above the sediments of Williams Lake, but this also was observed in May when the entire water column contained more than $9 \mathrm{mg} / \mathrm{L}$ of dissolved oxygen. These data indicate the difference in near-surface and near-bottom concentrations of total phosphorus may be due to another mechanism, an accumulation of particulate material originating in the epilimnion and the littoral areas of the lake (Rigler, 1973). 
Chiaudani and Vighi (1974) demonstrated that phytoplankton biomass is limited by phosphorus when the $\mathrm{N}: \mathrm{P}$ ratio is greater than 10:1 by weight. Total nitrogen and total phosphorus data indicate algal biomass levels in Williams Lake are limited by total phosphorus concentrations, because the $\mathrm{N}: \mathrm{P}$ ratio in the lake is $46: 1$ by weight. However, the factors controlling the maximum standing crop of all plant biomass in Williams Lake are not as readily identified because of the importance of the sediments as a nutrient source for aquatic macrophytes (Carignan and Kalff, 1980).

Carlson (1977) has developed an index for investigating the relationships between Secchi disk, total phosphorus, and chlorophyll values in lakes. Several Minnesota lakes were used by Carlson to demonstrate the use of the index. Carlson indicated that when these three characteristics are converted to the index values, they should be equal. The index formulation is based on empirical relationships between the three characteristics. The empirical relationship between phosphorus and chlorophy11 concentrations indicate phosphorus places a limit on chlorophyll concentration in lakes. The empirical relationship between chlorophyll and Secchi disk indicates they are inversely related. Data for all three characteristics in Williams Lake were available only from the August sampling date. Based on these data, index values of 37 (Secchi disk), 39 (total phosphorus), and 45 (chlorophyl1) were obtained, supporting the assumption that total phosphorus concentrations place a limit on algal biomass abundance (as measured by chlorophy11) in Williams Lake. These results also indicate Secchi-disk transparency and algal biomass are inversely related in Williams Lake. Chlorophy11 concentrations observed in this study fall in the range of moderately productive lakes presented by Likens (1975).

Concentrations of $\mathrm{SiO}_{2}$ in Williams Lake are much lower than the world freshwater average presented by Livingstone (1963). The $\mathrm{SiO}_{2}$ concentrations in Williams Lake are also lower than the average values presented by Bright (1968) for Minnesota Lakes in coniferous forests, deciduous forests, and prairie environments. There were no distinct significant statistical differences between near-surface and near-bottom samples for each date, and there was no distinct seasonal pattern in concentration changes from date to date in Williams Lake. These data indicate the mechanism of $\mathrm{SiO}_{2}$ depletion by the sedimentation of diatom frustules (Kalff and Knoechel, 1978), and subsequent release of dissolved silica from the sediments (Bailey-Watts, 1976) probably does not occur in Williams Lake. Wetzel (1975) has indicated $\mathrm{SiO}_{2}$ concentrations less than $0.5 \mathrm{mg} / \mathrm{L}$ are limiting for diatoms. Diatoms were the dominant component of the phytoplankton community in October, when $\mathrm{SiO}_{2}$ concentrations were $<0.5 \mathrm{mg} / \mathrm{L}$. Kalff and Knoechel (1978) have indicated diatoms are closely associated with isothermal periods of mixing, when their greater loss rates due to sinking are not a factor in placing them at a competitive disadvantage with other algae. Diatoms were dominant in Williams Lake only during the isothermal conditions in October, based on data collected in this study.

It is not clear why blue-green algae constitute the major component of the phytoplankton community in Williams Lake in May, July, August, and December. The high N:P ratio and absence of any pattern of nitrate 
depletion in Williams Lake preclude the common mechanisms attributed to blue-green algae dominance. When the N:P ratio is less than 5:1, nitrogen limits the phytoplankton and nitrogen-fixing blue-green algae become dominant (Schindler, 1977). The depletion of inorganic nitrogen in the euphotic zone gives a competitive advantage to nitrogen-fixing blue-green algae, which then can become dominant (Depinto and others, 1976).

The limited number of sampling dates in this study preclude identifying distinct patterns of seasonal succession in the zooplankton community of Williams Lake. However, the lake's zooplankton community does exhibit very general trends similar to those reported in the literature and discussed in detail by Hutchinson (1967). In Williams Lake, Dophnia were the major components of the zooplankton community in July, August, October, and December, and Daphnia maxima occurred in July and October. This pattern of population dynamics is one that is typical of the genus Dophnia discussed by Hutchinson (1967). Members of the genus Chydorus are primarily littoral species according to Hutchinson, occurring in the open water only in the summer. Chydorids in Williams Lake were important components of the limnetic zooplankton community only in August and October; the maximum for this study occurred in October. The genus Polyarthra has definite autumnal species (Hutchinson, 1967), and of all the rotifers in Williams Lake, only Polyarthra comprised more than 10 percent of the total numbers of zooplankton; this occurred in October.

\section{CONCLUSIONS}

1. Calcium bicarbonate geochemistry dominates Williams Lake and the contiguous ground-water system.

2. Based on geochemical and hydrologic data, the lake and the contiguous ground-water system interact.

3. Quartz, calcite, and dolomite were the major mineralogical constituents of the lake sediments. Marl was found in the littoral zones of the lake close to the shoreline. Loose organic floc and gyttja characterized the organic lake sediments.

4. The lake was dimictic and has high optical transparency.

5. Anaerobic conditions in the water column were not observed, despite the fact that the lake had clinograde oxygen distribution. Iron and manganese differed in their vertical distribution, coincident with clinograde oxygen distribution.

6. The lake was moderately fertile with respect to its nutrient content. Phytoplankton biomass levels appear to be limited by the lake's phosphorus content. 
7. In the open water season when the lake was stratified thermally, the dominant components of the phytoplankton communities were blue-green algae, the dominant component of the zooplankton communities were copepods and cladocerans. Aquatic macrophytes were abundant.

8. During isothermal conditions in the autumn, diatoms and rotifers were the dominant groups of their respective communities.

\section{REFERENCES}

Arneman, H. F., and others, 1969, Minnesota Soil Atlas, Brainerd Sheet: University of Minnesota Agricultural Experiment Station Miscellaneous Report 90-1969, $36 \mathrm{p}$.

Bailey-Watts, A. E., 1976, Planktonic diatoms and silica in Loch Leven, Kinross, Scotland: A one-month silica budget: Freshwater Biology, v. 6, p. 203-213.

Bright, R. C., 1968, Surface water chemistry of some Minnesota lakes, with preliminary notes on diatoms: University of Minnesota, Limnological Research Center Interim Report No. 3, $110 \mathrm{p}$.

Brown, Eugene, Skougstad, M. N., and Fishman, M. J., 1970, Methods of collection and analysis of water samples for dissolved minerals and gases: U.S. Geological Survey, Techniques of Water-Resources Investigations, Book 5, Chapter A-1, $160 \mathrm{p}$.

Carignan, R., and Kalff, J., 1980, Phosphorus sources for aquatic weeds: Water or Sediments? Science, v. 207, p. 987-989.

Carlson, R. E., 1977, A trophic state index for lakes: Limnology and Oceanography, v. 22, p. 361-369.

Chiaudani, G., and Vighi, M., 1974, The N:P ratio and tests with Selanastrum to predict eutrophication in lakes: Water Research, v. 8, p. 1063-1069.

DePinto, J. V., Bierman, V. J., and Verhoff, F. H., 1976, Seasonal phytoplankton succession as a function of species competition for phosphorus and nitrogen, in Canale, R. P., ed., Modeling biochemical processes in aquatic ecosystems: Ann Arbor, Michigan, Ann Arbor Science, p. 141-169.

Dillon, P. J., and Rigler, F. H., 1974, The phosphorus-chlorophyll relationship in lakes: Limnology and Oceanography, v. 19, p. 767-773.

Friedman, L. C., and Beetem, W. A., ed., 1980, Water quality laboratory services catalog: U.S. Geological Survey Open-File Report 79-697, $185 \mathrm{p}$.

Fries, Car1, Jr., 1938, Geology and ground water of the Trout Lake region, Vilas County, Wisconsin: Transactions of the Wisconsin Academy of Sciences, Arts, and Letters, v. 31, p. 305-322.

Garrels, R. M., and MacKenzie, F. J., 1971, Evolution of sedimentary rocks: New York, Norton, 397 p.

Groschen, G. E., 1981, Geochemistry of ground-water-lake systems in glacial drift: University of Minnesota, Minneapolis, M.S. thesis, unpublished, p. 8-11. 
Gorham, Eville, 1961, Factors influencing supply of major ions to inland waters, with special reference to the atmosphere: Geological Society of America Bulletin, v. 72, p. 795-840.

Greeson, P. E., Ehlke, T. A., Irwin, G. A., Lium, B. W., and Slack, K. V., eds., 1977, Methods for collection and analysis of aquatic biological and microbiological samples: U.S. Geological Survey, Techniques of Water-Resources Investigations, Book 5, Chapter A-4, $332 \mathrm{p}$.

Hem, J. D., 1970, Study and interpretation of chemical characteristics of natural waters: U.S. Geological Survey Water-Supp1y Paper 1473, 363 p.

Hutchinson, G. E., 1957, A treatise on limnology, Volume 1 - Geography, physics and chemistry: New York, John Wiley, 1015 p.

1967, A treatise on limnology, Volume 2 - Introduction to lake biology and the limnoplankton: New York, John Wiley, 1115 p.

Jones, B. F., and Bowser, C. J., 1979, The mineralogy and related chemistry of lake sediments, Chapter 7, in Lerman, A., ed., Lakes; chemistry, geology and physics: New York, Springer-Verlag, p. 179-235.

Kalff, J., and Knoechel, R., 1978, Phytoplankton and their dynamics in oligotrophic and eutrophic lakes: Annual Review of Ecology and Systematics, v. 9, p. 475-495.

Kelts, K., and Hsu, K. J., 1979, Freshwater carbonate sedimentation, in Lerman, A., ed., Lakes; chemistry, geology, and physics: New York, Springer-Verlag, p. 295-323.

Likens, G. E., 1975, Primary production of inland aquatic ecosystems, in Lieth, H., and Whittaker, R. H., eds., Primary production of the biosphere: New York, Springer Verlag, p. 185-202.

1976, Acid precipitation: Chemical Engineering News, v. 22, p. 29-44.

Livingstone, D. A., 1963, Chemical composition of rivers and lakes, Chapter G, Data of Geochemistry, 6th Edition: U.S. Geological Survey Professional Paper 440-G, 64 p.

Mortimer, C. H., 1941, The exchange of dissolved substances between mud and water in lakes 1: Journal of Ecology, v. 29, p. 280-329.

1942 , The exchange of dissolved substances between mud and water in lakes 2: Journal of Ecology, v. 30, p. 147-201.

P1ummer, L. N., Jones, B. F., and Truesche11, A. H., 1976, WATEQF, a FORTRAN IV version of WATEQ, a computer program for calculating chemical equilibrium of natural waters: U.S. Geological Survey Water-Resources Investigation $76-13,61 \mathrm{p}$.

Rigler, F. H., 1973, A dynamic view of the phosphorus cycle in lakes, in Griffith, E., and others, eds., Environmental phosphorus handbook: New York, John Wiley, p. 539-572.

Schindler, D. W., 1977, Evolution of phosphorus 1imitation in 1akes: Science, v. 195, p. 260-262.

Seyb, Les, and Randolph, Karen, 1977, North American Project--a study of U.S. water bodies: U.S. Environmental Protection Agency, Ecological Research Series, EPA-600/3-77-086, 537 p.

Shoaf, W. T., and Lium, B. W., 1977, The quantitative determination of chlorophylls $a$ and $b$ from freshwater algae without interference from degradation products: U.S. Geological Survey Journal of Research, v. 5, p. 263-264. 
Siegel, D. I., and Winter, T. C., 1980, Hydrologic setting of Williams Lake, Hubbard County, Minnesota: U.S. Geological Survey Open-File Report 80-403, $56 \mathrm{p}$.

Skougstad, M. W., Fishman, M. J., Friedman, L. C., Erdmann, D. E., and Duncan, S. S., (eds.), 1979, Methods for determination of inorganic substances in water and fluvial sediments: U.S. Geological Survey, Techniques of Water-Resources Investigations, Book 5, Chapter A-1, $626 \mathrm{p}$.

Tarapchak, S. T., 1973, Studies on phytoplankton distribution and indicators of trophic state in Minnesota lakes: University of Minnesota, Ph.D. dissertation, 223 p.

U.S. Environmental Protection Agency, 1979, Lake restoration: Proceedings of a National Conference, August 1978, Minneapolis, Minnesota, U.S. Environmental Protection Agency, EPA-440/5-79-001, 254 p.

Wetze1, R. G., 1975, Limnology: Philadelphia, W. B. Saunders, 743 p. Winter, T. C., 1980, Survey of errors for estimating water and chemical balances of lakes and reservoirs: Proceedings of Symposium on SurfaceWater Impoundments, American Society of Civil Engineers, P. 224-233. 1981, Uncertainties in estimating the water balance of lakes: Water Resources Bulletin, v. 17, no. 1, p. 82-115.

Wood, W. W., 1976, Guidelines for collection and field analysis of groundwater samples for selected unstable constituents: U.S. Geological Survey, Techniques of Water-Resources Investigations, Book 1, Chapter D2, 24 p. 